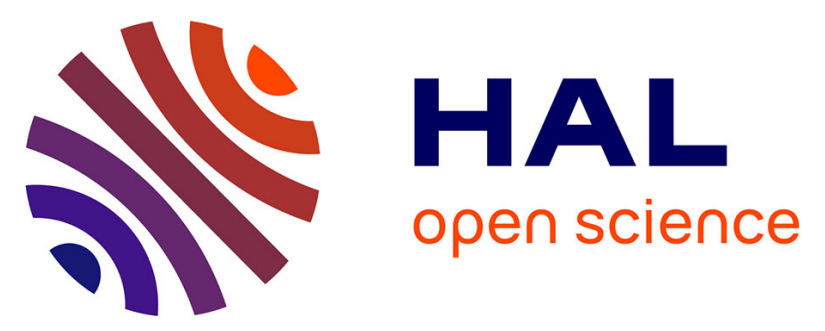

\title{
Lost islands in the northern Lesser Antilles: possible milestones in the Cenozoic dispersal of terrestrial organisms between South-America and the Greater Antilles
}

Jean-Jacques Cornee, Philippe Münch, Mélody Philippon, Marcelle

Boudagher-Fadel, Frédéric Quillévéré, Mihaela Melinte-Dobrinescu, Jean-Frédéric Lebrun, Aurélien Gay, Solène Meyer, Lény Montheil, et al.

\section{To cite this version:}

Jean-Jacques Cornee, Philippe Münch, Mélody Philippon, Marcelle Boudagher-Fadel, Frédéric Quillévéré, et al.. Lost islands in the northern Lesser Antilles: possible milestones in the Cenozoic dispersal of terrestrial organisms between South-America and the Greater Antilles. Earth-Science Reviews, 2021, 217, pp.103617. 10.1016/j.earscirev.2021.103617 . hal-03191176

\author{
HAL Id: hal-03191176 \\ https://hal.science/hal-03191176
}

Submitted on 6 Apr 2021

HAL is a multi-disciplinary open access archive for the deposit and dissemination of scientific research documents, whether they are published or not. The documents may come from teaching and research institutions in France or abroad, or from public or private research centers.
L'archive ouverte pluridisciplinaire HAL, est destinée au dépôt et à la diffusion de documents scientifiques de niveau recherche, publiés ou non, émanant des établissements d'enseignement et de recherche français ou étrangers, des laboratoires publics ou privés. 
Lost islands in the northern Lesser Antilles: possible milestones in the Cenozoic dispersal of terrestrial organisms between South-America and the Greater Antilles

Jean-Jacques Cornée ${ }^{1}$, Philippe Münch ${ }^{2}$, Mélody Philippon ${ }^{1}$, Marcelle BouDagherFadel $^{3}$, Frédéric Quillévéré ${ }^{4}$, Mihaela Melinte-Dobrinescu ${ }^{5}$, Jean-Frédéric Lebrun ${ }^{1}$, Aurélien $\mathrm{Gay}^{2}$, Solène Meyer ${ }^{2,6}$, Lény Montheil ${ }^{2}$, Serge Lallemand ${ }^{2}$, Boris Marcaillou ${ }^{6}$, Muriel Laurencin ${ }^{7}$, Lucie Legendre ${ }^{1}$, Clément Garrocq $^{2}$, Milton Boucard ${ }^{1}$, Marie-Odile Beslier $^{6}$, Mireille Laigle ${ }^{6}$, Laure Schenini ${ }^{6}$, Pierre-Henri Fabre ${ }^{8}$, Pierre-Olivier Antoine ${ }^{8}$, Laurent Marivaux ${ }^{8}$ and the GARANTI and ANTITHESIS Scientific Parties.

The GARANTI Scientific Party is composed of:

Agranier, A., Arcay, D., Audemard, F., Beslier, M.O., Boucard, M; Cornée, J.J., Fabre, M., Gay, A., Graindorge, D., Klingelhoefer, A. Heuret, F., Laigle, M., Lallemand, S., Lebrun J.F., Léticée, J.L., Malengro, D., Marcaillou, B., Mercier de Lepinay, B., Münch, P., Oliot, E., Oregioni, D., Padron, C., Quillévéré, F., Ratzov, G., Schenini, L. and Yates, B., J.F.

The ANTITHESIS Scientific Party is composed of: Bouquerel, H., Conin, M., Crozon, J., Dellong, D., De Min, L., de Voogd, B., Evain, M., Fabre, M., Graindorge, D., Gwandai, W., Heuret, A., Klingelhoefer, F., Laigle, M., Lallemand, S., Laurencin, M., Lebrun, J.-F., Legendre, L., Lucazeau, F., Mahamat, H., Marcaillou, B., Mazabraud, Y., Pichot, T., Prunier, C., Renouard, A., Rolandonne, F., Rousset, D., Schenini, L., Thomas, Y., Vitard C.

${ }^{1}$ Géosciences Montpellier, CNRS-Université des Antilles-Université de Montpellier, F-97159 Pointe à Pitre, Guadeloupe, France

${ }^{2}$ Géosciences Montpellier, CNRS-Université de Montpellier-Université des Antilles, F-34095 Montpellier, France

${ }^{3}$ Office of the Vice-Provost (Research), University College London, 2 Taviton Street, London WC1H OBT, UK

${ }^{4}$ Université Claude Bernard Lyon 1, ENS de Lyon, CNRS, UMR 5276 LGL-TPE, F-69622

Villeurbanne, France 
${ }^{5}$ National Institute of Marine Geology and Geoecology, 23-25 Dimitrie Onciul Street, PO

Box 34-51, 70318 Bucharest, Romania

${ }^{6}$ Geoazur, Université de la Côte d'Azur, CNRS, Observatoire de la Côte d'Azur, IRD, F-

06560 Valbonne, France

${ }^{7}$ Laboratoire d'Océanologie et Géosciences, Université de Lille, 59655 Villeneuve d'Ascq,

France

${ }^{8}$ Institut des Sciences de l'Evolution de Montpellier (ISE-M), Univ Montpellier, CNRS, IRD, EPHE, F-34095 Montpellier, France

Corresponding author: Jean-Jacques Cornée, jean-jacques.cornee@gm.univ-montp2.fr

Université des Antilles, Dépt. Géologie, Campus de Fouillole, F-97159 Pointe à Pitre Cedex, Guadeloupe, FWI

Keywords: Lesser Antilles, Cenozoic basins, biostratigraphy, seismic stratigraphy, palaeogeography, vertical motions

\section{ABSTRACT}

Our study aims to reconstruct the palaeogeography of the northern part of the Lesser Antilles in order to analyse whether emerged areas might have existed during the Cenozoic, favouring terrestrial faunal dispersals between South America and the Greater Antilles along the present-day Lesser Antilles arc. The stratigraphy and depositional environments of the islands of Anguilla, St Martin, Tintamarre, St Barthélemy, Barbuda and Antigua are reviewed in association with multichannel reflection seismic data acquired offshore since the 80 's in the Saba, Anguilla and Antigua Banks and in the Kalinago Basin, including the most recent academic and industrial surveys. Seven seismic megasequences and seven regional unconformities are defined, and calibrated from deep wells on the Saba Bank and various dredges performed during marine cruises since the 70's in the vicinity of the islands. Onshore and offshore correlations allow us to depict an updated and detailed sedimentary organisation of the northern part of the Lesser Antilles from the late Eocene to the late Pleistocene. Paleogeographic reconstructions reveal sequences of uplift and emergence across hundredswide areas during the late Eocene, the late Oligocene, the early middle-Miocene and the latest Miocene-earliest Pliocene, interspersed by drowning episodes. The $\sim 200 \mathrm{~km}$-long and $\sim 20$ $\mathrm{km}$-wide Kalinago Basin opened as an intra-arc basin during the late Eocene - early Oligocene. These periods of emergence may have favoured the existence of episodic mega-islands and transient 
terrestrial connections between the Greater Antilles, the Lesser Antilles and the northern part of the Aves Ridge (Saba Bank). During the Pleistocene, archipelagos and mega-islands formed repeatedly during glacial maximum episodes.

\section{INTRODUCTION}

The Caribbean, including the Greater and Lesser Antilles located at the northeastern edge of the Caribbean Plate, are regarded as one of the most important centres of insular biodiversity (Myers al., 2000; Mittermeier et al., 2011). Despite decades of studies, the phylogenetic origins and historical biogeography of this astonishing biodiversity remain, however, controversial (e.g., Hedges et al., 1992; MacPhee and Iturralde-Vinent, 1995, 2005; Iturralde-Vinent and MacPhee, 1999; Myers et al., 2000; Hedges, 2001, 2006; Ali, 2012). In an island setting, either over-water transports (natural rafts of matted vegetation) or land connections provide possible routes for dispersal of terrestrial organisms and their colonization of these remote Caribbean islands. If over-water dispersals by rafting are sweepstake dispersals (and as such hardly predictable), the possibility of over-land (via landbridges) dispersals relies on the regional tectono-magmatic evolution of the Lesser Antilles subduction zone.

Biogeographic models for Antillean terrestrial organisms derive from limited palaeontological and phylogenetic inferences (either based on the morphology or on genes/proteins of living and recently extinct species) (Hedges, 1996; Woods et al., 2001; Graham, 2003; Roca et al., 2004; MacPhee, 2005; Fabre et al., 2014; Brace et al., 2015, 2016; Courcelle et al., 2019; Delsuc et al., 2019; Presslee et al., 2019; Marivaux et al., 2020). They also derive from still controversial paleogeographic models of the Caribbean Plate evolution (e.g., Stephan et al., 1990; Iturralde-Vinent and MacPhee, 1999; Pindell and Kennan, 2009) and global reconstructions (Blakey, https://deeptimemaps.com/; Scotese; 2016). The main 
discussed model for explaining the arrival of many terrestrial organisms of South American origin on the Caribbean islands relate to a possible 2 Myrs- long period of subaerial exposure of the Aves Ridge (Fig. 1) at the Eocene-Oligocene transition. Following this model, the ridge momentarily constituted a land-bridge (named GAARlandia, for land of Greater AntillesAves Ridge) between northern South America and the Greater Antilles (e.g., MacPhee and Iturralde-Vinent, 1995; Iturralde-Vinent and MacPhee, 1999; MacPhee, 2005; IturraldeVinent, 2006)).

Contrary to the Aves Ridge, the potential contribution of the Lesser Antilles in early dispersals of South American faunas and flora has never been considered. This is paradoxical because the archipelago is located closer to the subduction deformation front and has experienced uplift and drowning events likely favouring land-organism dispersals and subsequent insular evolution. This is particularly obvious in the Guadeloupe archipelago where repeated uplifts, leading to subaerial exposures, and subsequent drownings have been evidenced (Cornée et al., 2012; Münch et al., 2013, 2014; De Min et al., 2014). Further north, it has been proposed that the Pleistocene rodent Amblyrhiza, an endemic giant chinchilloid caviomorph from Anguilla, St Martin and St Barthélemy islands, could be closely related to early Oligocene chinchilloids from Puerto Rico (Velez-Juarbe et al., 2014; Marivaux et al., 2020), thereby extending the evolutionary history of this rodent group back to $30 \mathrm{Ma}$, and revealing its widespread distribution between the Greater Antilles and the northern Lesser Antilles through time.

In this work, we study the palaeogeographic evolution of the northeastern part of the Lesser Antilles during the Cenozoic, as it may have constituted an episodic emerged area between the Aves Ridge to the southwest and the Greater Antilles to the North: the GrANoLA land -Greater Antilles- Northern Lesser Antilles land (Philippon et al., 2020a). Previous bathymetric reconstructions and offshore-onshore geological investigations have suggested 
that the Kalinago intra-arc rift basin (Figs. 1,2) may have undergone substantial vertical motion (e.g., Bouysse et al., 1985a; Mann et al., 1995; Feuillet et al., 2011) and 15\% extension (Legendre et al., 2018). In the whole Eastern Caribbean (Aves Ridge, Greater and Lesser Antilles), accurate constraints on the chronology, duration and spatial extent of land emergence and drowning during the Cenozoic are, however, strongly missing to reconstruct the regional paleogeographic evolution. This lack of information prevents the effective testing of biogeographic models deriving from gene-based and morpho-anatomical phylogenies and associated divergence time estimates. In this work, we refine the sedimentology and stratigraphy of the deposits over an area extending from the Saba Bank to the Antigua Bank encompassing the Kalinago Basin (Figs. 1, 2), and use these analyses to reconstruct the vertical motions that occurred in this key area of the Northern Lesser Antilles. The study is based on new onshore palaeoenvironmental, biostratigraphic, and structural data, combined and correlated with new offshore-dredged samples and seismostratigraphic interpretation of seismic reflection data from the ANTITHESIS (Marcaillou and Klingelhoefer, 2013; 2016) and GARANTI cruises (Lebrun and Lallemand, 2017), which allow us to reconstruct the palaeogeographic evolution of the region.

\section{TECTONO-MAgMATIC EVOLUTION OF THE NE CARIBBEAN SINCE THE CRETACEOUS} Caribbean Plate initiated from Cuba southward during the Cretaceous. The Great Arc of the Caribbean (GAC) is the magmatic expression of this subduction. Magmatic arc samples from the southern Aves Ridge and Leeward Antilles offshore Venezuela indicate that subduction occurred there since the middle-late Cretaceous (Coniacian; Neill et al., 2011) or after 
Santonian (Hastie et al., 2021). During the Paleocene and the early Eocene, the motion of the

142 North American Plate relative to the Caribbean plate changed from north-eastward to eastward (Pindell and Kennan, 2009; Boschman et al., 2014). At the same time, the collision of the Bahamas Bank margin with the Caribbean Plate sutured the subduction along its northern part (accreting Cuba to the North American plate) whereas a new E-W trending transform plate boundary formed along the proto-Cayman Trough that started opening (e.g., Pindell and Kennan, 2009; Boschman et al., 2014). Subsequently, the Greater Antilles underwent sinistral shearing and were dismembered along the new transform plate boundary

(Fig. 1). The present-day trench curvature of the northern Lesser Antilles subduction zone and along strike variation of the convergence obliquity most likely results from this Eocene reorganisation of the plate boundary and subsequent left lateral motion of the Bahamas Bank / Cuba margin relative to the Caribbean Plate interior (Boschman et al., 2014; Philippon and Corti, 2016; Philippon et al., 2020b). Today, the Greater and Lesser Antilles margins are separated by an elongated, fault-bounded basin, the Anegada Trough (e.g., Jany et al., 1990; Laurencin et al., 2017 and references therein; Fig. 1). Based on dredged samples and seismic reflection profiles, the opening of the Anegada Trough is supposed to have occurred during the middle or the late Miocene (Jany et al., 1990), and its activity has probably been negligible since 2 Ma (Chaytor and ten Brink, 2015; Calais et al., 2016). Our study area lies south of this major tectonic structure separating the Greater from the Lesser Antilles (Fig. 1). lateral variation with time:

(i) arc magmatism was first established during the Late Cretaceous-Paleocene along the Aves Ridge (Fig. 1) as part of the GAC (ages of arc magmatic rocks range between $88 \mathrm{Ma}$ and 59 Ma; Fox et al., 1971; Bouysse et al., 1985a; Neill et al., 2011). 
(ii) The GAC then migrated eastward (i.e., trenchward) probably during the middle 166 Eocene, as evidenced by the occurrence of Lutetian lavas in the Grenadines Islands

(Westercamp et al., 1985). This Eocene arc is present beneath the southern Lesser Antilles islands, and, from Martinique northward, Eocene to earliest Miocene remnants of this arc are exposed and dated in the forearc domain (Westercamp, 1988; Bouysse and Westercamp, 1990; Legendre et al., 2018) (Fig. 1). Along the northern Lesser Antilles, this arc is exposed and dated based on radiometric data in Antigua (middle Eocene to earliest Miocene; Nagle et al., 1976; Briden et al., 1979; Mascle and Westercamp, 1983; Weiss, 1994), St Barthélemy (middle Eocene to latest Oligocene; Legendre et al., 2018), and St Martin (late Eocene to early Oligocene; Nagle et al., 1976; Briden at al., 1979). Late Paleogene volcaniclastic arc (or backarc) rocks have also been found in deformed zones of the Virgins Islands, Puerto-Rico and Anguilla (Briden et al., 1979; Andréïeff et al., 1988; Jolly et al., 1998; Rankin, 2002), thereby suggesting that the remnant arc extended across the incipient Anegada Trough at this time. These rocks, nevertheless, have never been related neither to those of the Aves Ridge nor to those of the Grenada Basin.

(iii) The modern arc (inner arc of Mc Cann and Sykes, 1984) is formed $50 \mathrm{~km}$ west of the late Paleogene-early Neogene remnant one (outer arc of Mc Cann and Sykes, 1984). From Guadeloupe northward, volcanism occurred since the early Pliocene (e.g., Samper et al., 2007; Favier et al., 2019; Carey et al., 2020). The northernmost island of the arc is Saba where volcanism occurred during the Late Pleistocene (Defant et al., 2001). Offshore north of Saba, Pliocene volcanic and volcaniclastic rocks have been dredged from the Luymes Bank (cruise ARCANTE 1) and the Noroît Seamount (cruise ARCANTE 3, 118) (Figs. 1 and 2) (Bouysse et al., 1981; 1985b). 


\subsection{Anguilla Bank}

192

193

194

195

196

197

198

199

200

201

202

203

204

205

206

207

208

Three main islands emerge from the large, shallow water Anguilla Bank: from north to south Anguilla, St Martin (including the islet of Tintamarre) and St Barthélemy (Fig. 2). Neogene deposits are exposed on these three islands (Christman 1953; Andréïeff et al., 1987; 1988; older references therein).

St Martin consists of 2000 to 3000 m-thick Eocene volcaniclastic turbidites intruded by late Eocene-early Oligocene granodiorites (28.4-31.3 Ma; Nagle et al., 1976; Briden et al., 1979). In the southwestern part of the island, late Oligocene magmatic rocks may also occur but remain undated (Andréïeff et al., 1988, 1989). On the southwestern and eastern margins of the island, Neogene carbonates deposited unconformably on Paleogene rocks, which were tilted along a NE-SW fault bounding the northwestern coast of the island. Drilled cores from the southwestern deposits recovered up-to- $250 \mathrm{~m}$ of Neogene carbonates along the margin of the island (Terres Basses; Dagain et al., 1989). On the islet of Tintamarre, the basal part of the Neogene deposits remains unknown. According to Andréïeff et al. (1988), the deposits at St Martin and Tintamarre constitute two main formations with unknown relationships: 1) > 70 m- thick sedimentary rocks which were deposited during the late Burdigalian in a reefal depositional setting; 2) $80 \mathrm{~m}$ - thick distal forereef sedimentary rocks which were deposited between the late Serravallian and the Messinian in St Martin only.

In the island of Anguilla, the oldest sedimentary deposits consist of late Paleocene to Eocene volcaniclastic turbidites tilted to the south-east (Andréieff et al., 1988). These turbidites are unconformably overlaid by a $100 \mathrm{~m}$ - thick biostromal coral reef deposit considered to be either early Miocene or middle Miocene (Andréïeff et al., 1988; Budd et al., 2005). Shallow water carbonates are poorly known from other islets of the Anguilla Bank, 
Sombrero (Pliocene) and Dog Islands (late Burdigalian-early Langhian; Bouysse et al., 1985a; Andréïeff et al., 1987).

During the cruises ARCANTE, dredged samples have been collected on flanks of the Anguilla Bank (Bouysse and Guennoc, 1983; Bouysse et al., 1985a) (Fig. 2). On the southwestern margin of the Anguilla Bank, dredges $46 \mathrm{~V}$ and $47 \mathrm{~V}$ yielded Pleistocene to Holocene carbonate sediments. On the northern margin, dredge 121D provided Pliocene-? Pleistocene tuff limestones, Serravallian marls, and late Eocene magmatic rocks (36.5 to 33 Ma interval, whole rock K-Ar ages; Bouysse et al., 1985a). Finally, to the east of the Bank, dredges E402 and ST31 yielded uppermost Cretaceous radiolarian-bearing limestones and Pleistocene clays, respectively.

\subsection{Kalinago Basin}

The Kalinago Basin is a NW-SE trending, $100 \mathrm{~km}$ - long intra-arc rift separating the Anguilla Bank from the recent active volcanic arc (Bouysse et al., 1985a; Jany et al., 1990) (Fig. 2). The basin is bounded by syn- to post- Neogene faults and possibly comprise deformed, Cretaceous to Oligocene or Miocene rocks overlain by poorly deformed, $2.000 \mathrm{~m}$ thick Neogene to Pleistocene deposits (Jany, 1989; Jany et al., 1990; Church and Allison, 2004). At the northern margin of the basin on slopes of the Aguillita Spur, dredge RVEastward 1390 (Fig. 2) yielded clays and marls that were deposited between the Pliocene and the Pleistocene (Jany, 1989). In the southern part of the basin, southeast of Montserrat (Fig. 2), the Integrated Ocean Drilling Program (IODP) Leg 340 (out of Fig. 2) drilled $181 \mathrm{~m}$ of late Pleistocene volcaniclastic deposits (Coussens et al., 2012).

\subsection{Saba Bank}


The shallow water Saba Bank (Figs. 1 and 2) has been intensively explored for oil prospecting (Warner, 1990; Larue and Warner, 1991; Daly, 1995; Church and Allison, 2004; Matchette-Downes, 2007). On the basis of seismic investigations and wells SBD1 (total depth of 2977 m; Marathon Group) and SBD2 (total depth of 4231 m; Fina Group), the bank comprises from bottom to top: 1) a deformed Cretaceous to Paleocene sedimentary basement topped by an unconformity; 2) a subaerial, at least $120 \mathrm{~m}$ - thick, porphyritic andesitic sequence dated at $34.4 \pm 3.7 \mathrm{Ma}$ and $37.3 \pm 1.4 \mathrm{Ma}$ (whole rock K-Ar); 3) a ca 900 to 1000 m- thick "turbidite" unit dated from the early late Eocene to the early Oligocene based on planktonic foraminifera and calcareous nannofossils; this unit correlates with late Eocene reefs developed on palaeostructural highs; 4) a $c a 1500 \mathrm{~m}$ - thick volcaniclastic "fluviodeltaic" unit, which were deposited between the early late Oligocene and the early Miocene based on calcareous nannofossils and benthic foraminifera, and 5) an "upper carbonate unit", which was deposited between the middle Miocene and the early Pliocene based on planktonic foraminifera, and which indicates a shallowing-upward trend (Church and Allison, 2004).

North of the Saba Bank, a Pliocene ( $c a 4 \mathrm{Ma}$ ) volcanic activity has been evidenced on the Luymes Bank and the Noroît Seamount and may correspond to the northeastern termination of the active volcanic Lesser Antilles Arc (Bouysse et al., 1985a; b). Along with volcanic rocks and clasts, Pliocene-Pleistocene pelagic limestones were mainly recovered and coral reefs and red-algal limestones were also dredged. Finally, one dredge (119D) south of the Noroît Seamount yielded some porphyritic andesite fragments dated at $66.5 \pm 1.5 \mathrm{Ma}$ (whole rock K-Ar; Bouysse et al., 1985a), corresponding, like in the Saba Bank and St Croix Island, to the Maastrichtian-Danian GAC basement (Speed et al., 1979) (Fig. 2).

\subsection{Antigua Bank}


The Antigua island comprises three main lithostratigraphic units with an estimated total thickness of $2.500 \mathrm{~m}$. These units are tilted northeastward on the footwall of the normal faults forming the NE side of the Kalinago Basin (e.g., Martin Kayes, 1969; Frost and Weiss, 1979; Mascle and Westercamp, 1983; Multer et al., 1986; Weiss, 1994; Donovan et al., 2014; Robinson et al., 2017): 1) the Basal Volcanic Complex (1500 m- thick), poorly constrained as either middle Eocene or Oligocene (39.7-23 Ma; in Briden et al., 1979); 2) the Central Plain Group (500 m- thick), composed of volcaniclastic deposits with freshwater and marine limestones, supposed to have been deposited during the Oligocene (Mascle and Westercamp, 1983; Robinson et al., 2017); 3) the late Oligocene Antigua Formation, composed of shallow water limestones evolving eastward into deep marine limestones.

The Barbuda island consists of four shallow water carbonate formations (Fm.) separated by subaerial erosional surfaces (Brasier and Mather, 1975), from bottom to top: the Highland Fm. (bank edge facies, 40 m- thick at least), Beazer Fm. (fringing reefs, 5 m- thick; Pleistocene), Codrington Fm. (fringing and barrier reefs, $5 \mathrm{~m}$ - thick; late Pleistocene) and Palmetto Fm. (eolian dunes, reef, lagoon, and beach deposits, $10 \mathrm{~m}$ - thick; Holocene). The age of the Highland Fm. is still debated: Oligocene (Reed, 1921), middle Miocene (Brasier and Mather, 1975), early Pliocene (Brasier and Donahue, 1985; Watters et al., 1991) or Pleistocene (Russell and Mc Intire, 1966; Land et al., 1967; Martin Kaye, 1969).

Four dredges performed during the ARCANTE cruises provided reliable information (Andréïeff et al, 1980; Bouysse and Guennoc, 1983) (Fig. 2). On the western margin of the Antigua Bank (also eastern margin of the Kalinago rift), dredge 71D yielded Pliocene to Pleistocene bioclastic limestones from an outer reef depositional setting. On the eastern side of the bank, dredge 79D, collected between 1,800 and 2,000 m depths, yielded late Oligocene carbonates from outer-ramp setting and early Miocene pelagic micritic limestones. Above, at 
$480 \mathrm{~m}$ depth, dredge 80D yielded late Miocene marls and Pliocene pelagic carbonate deposits. On top the of the bank, at $30 \mathrm{~m}$ depth, dredge $78 \mathrm{~V}$ yielded recent reefal limestones.

\section{METHODS AND DATA}

\subsection{Rock-samples analyses}

New field investigations were conducted in 2015, 2017 and 2020 onshore in Anguilla, St Martin and Tintamarre islands with respectively 7, 7 and 6 logged and sampled sections (Appendices C, D, E). For biostratigraphic analyses, 18 samples were collected in Anguilla, 17 in St Martin and 24 in Tintamarre. Combined with field-investigations and sedimentological information, the biostratigraphic analyses allow a correlation between the sections and provide a revised lithostratigraphic sketch of the onshore Neogene deposits of the Anguilla Bank. This onshore sampling was completed by seven offshore carbonate samples collected from three rock-dredge hauls carried out during the GARANTI cruise (Fig. 2): Dredge DR GA-04-01 was collected on the northern steepest flank of the Martinita Seamount; Dredge DR GA-04-02 was collected on the southern flank of this Martinita Seamount ; and Dredge GA-03-01 was collected on the Southeastern Spur (Appendix I). For the island of St Barthélemy, we use the recently published results of Cornée et al. (2020) (Appendix G). In Barbuda, we logged and sampled the Highland Fm. (Appendix F) in 2006; 19 samples were collected. In Antigua, 10 samples were chosen for thin sections in order to refine the age of the Antigua Fm. (Appendix G).

Across the whole studied area, a total of 125 polished thin sections were obtained from each carbonate rock-type sample in order to analyse their microfacies and fossil content. The identified microfacies were attributed to a depositional environment following the classification of Wright and Burchette (1996), supplemented by the larger benthic 
foraminiferal content (BouDagher-Fadel, 2008) (e.g., Appendix B). In addition, 18 soft rock samples were washed over a $65 \mu \mathrm{m}$ screen and the residues were analysed for foraminiferal biostratigraphy. Finally, standard smear-slides were also prepared for 14 of these soft rock samples for calcareous nannofossil analyses (Appendix A). Our biostratigraphical analyses are based on a complete inventory of larger benthic foraminifera, planktonic foraminifera and calcareous nannofossil taxa found in the thin sections and standard smear-slides. We used the zonal schemes and bio-events calibrations of BouDagher-Fadel $(2013,2015,2018)$ for planktonic and larger benthic foraminifera, and those of Backman et al. (2012) for calcareous nannofossils, which have been calibrated against the time scale of Gradstein et al. (2012).

Finally, we used the $\mathrm{Ar}^{40} / \mathrm{Ar}^{39}$ method to date a large boulder $(50 \mathrm{~cm})$ of a fresh porphyritic andesite reworked in submarine lahar deposits overlain by Neogene limestones in the southwestern part of St Martin Island (details are given in Appendix K).

\subsection{Seismic reflection profiles}

We analyzed eight new profiles from the GARANTI cruise that occurred in 2017 on board L'Atalante R/V (Lebrun and Lallemand , 2017), together with a set of multichannel reflection seismic lines recorded during cruises ANTITHESIS 1 (2013) and 3 (2017) (Marcaillou and Klingelhoefer, 2013; 2016) (Fig. 2). Acquisition parameters for the selected MCS lines include a 3.902 inche $^{3}$ airgun array source and a 720 channels- $6.25 \mathrm{~m}$ trace spacing streamer ensuring a 120-fold coverage. Quality control and binning of the MCS data were performed on board using QCSispeed ${ }^{\circledR}$ and SolidQC® (Ifremer), and processing was performed using GEOVATION® (CGG). Processing sequence includes band-pass (2-7-60$80 \mathrm{~Hz}$ ) and FK filtering, Spherical divergence and amplitude (gain) correction, predictive deconvolution, three steps velocity analysis and Normal Move-Out (NMO) correction, external mutes, internal mutes and further multiple attenuation by 2D-Surface-Related 
Multiple Elimination and Radon domain filtering, velocity stack and constant velocity $(1500 \mathrm{~m} / \mathrm{s}) \mathrm{FK}$ migration.

Our data set also includes petroleum seismic data acquired in $2 \mathrm{D}$ in the 80 's over the Saba Bank and an industrial database on the Saba Bank (Fina 1980; Aladdin 1988). These seismic data, described in Church and Allison (2004), show a lower resolution as compared to those of the GARANTI and ANTITHESIS lines. They allow us, however, to extend our interpretation to a zone that is nowadays closed to seismic investigations. We also benefited from other seismic lines from the "Comité d'Etude Pétrolière et Marine" (CEPM) under the supervision of the "Institut Francais du Pétrole et des Énergies Nouvelles" (IFPEN) acquired in the 70's during the Antilles IV cruise (e.g., Bouysse et al., 1985a; b; Bouysse and Mascle, 1994). The seismic stratigraphy of the Saba Bank petroleum surveys was calibrated by using two exploration wells (SBD1 and SBD2; Church and Allison, 2004). The CPEM lines in the vicinity of the Antigua Bank were calibrated using offshore-onshore correlations (Legendre, 2018), wells IODP 340 (Coussens et al., 2012) and dredges ARCANTE 1 (Andréïeff et al., 1980).

Seismic facies and units are determined following the classical criteria of Mitchum and Vail (1977) and Roksandic (1978).

\subsection{Onshore}

\subsubsection{Anguilla}

Seven sections of Anguilla (Appendix C) yielded stratigraphically significant taxa of larger benthic foraminifera (Appendix B) and calcareous nannofossils (Appendix A). Based on the identified taxa, we were able to date each of the logged and sampled sections (Fig. 3). 
Above Paleogene turbiditic beds tilted to the SE (Crocus Bay section; Andréieff et al., 1988) (Fig. 4A), we found $60 \mathrm{~m}$ - thick coral boundstones organized into coral banks and low-relief domes where platy and massive colonies dominate (Fig. 4, B, C, E, F). Associated with the boundstones, we found some bioclastic packstones with abundant corals, larger benthic foraminifera (miogypsinids, amphisteginids, miliolids, and soritids, e.g., Archaias), echinoids, red algae, mollusks (pectinids and oysters), and frequent Teredo in life position (Fig. 4D). Ten genera and eighteen species of hermatypic corals occur in this platform, among which the Porites genus is dominant, the next most abundant being Montastraea and Stylophora (Budd et al., 1995). Our biostratigraphic analyses indicate that the succession encompasses the Aquitanian to Tortonian-Messinian interval (N4-N18, 23-5.33 Ma) and, except the local occurrence of hardgrounds, no clear evidence of hiatuses has been found in the field. Beds are vertically stacked but low-angle cross-bedded units were found prograding southeastward along the southern coast (e.g., localities ANG3, 9 and 10) and in the northeastern part of the island (ANG 6) (Appendix C).

The Neogene deposits of Anguilla likely correspond to those of an isolated shallow reefal, protected inner platform (Fig. 3), as already suggested by Budd et al. (2005) based on the study of some coral build-ups. This platform contains units with prograding beds towards the SE, indicating that it was opening towards a deeper marine setting.

\subsubsection{St Martin}

Above tilted Paleogene volcaniclastic rocks, the succession of the southwestern part of the island comprises, from bottom to top (Fig. 5; localities in Appendix D):

1. 10 to $\mathbf{1 8} \mathrm{m}$ - thick coral reef boundstones and associated bioclastic packstones (Fig. 6A to C). In the Sabannah area, $4 \mathrm{~m}$ - high patch reefs with branching colonies are exposed. Larger benthic foraminifera are mainly represented by miogypsinids and 
amphisteginids. Planktonic foraminifera (globigerinids) and calcareous nannofossils are also present. At Mullet Bay, we found cross-bedded packstones with red algae and foraminifera and some coral beds. The benthic foraminiferal assemblages are dominated by amphisteginids and Asterigerina. Elsewhere, in the Juliana Bay and Kool Hill sections, well bedded bioclastic limestones and coral banks are exposed. Foraminifera are dominated by Archaias, Praerhapydionina, Cyclorbiculina, Miosorites, Androsinopsis and Miarchaias, associated with small miliolids and textulariids. At Kool Hill, karstic cavities infilled by red silty clays and associated with a paleosol level indicate a temporary emersion (Fig. 7C). Our biostratigraphical analyses indicate that the lower part of these deposits correlates with planktonic foraminiferal Zone N5 (latest Aquitanian-early Burdigalian, 21-18 Ma) and the upper part with Zones N6-N8a (late Burdigalian, 18-15.97 Ma) (Appendix D). The late Burdigalian deposits of the Juliana Airport road section (Fig. 7A) are affected by synsedimentary normal faults (Fig. 7A, B) associated with a local subaerial erosion surface with karstic gullies. Karstic microcaves were found only below this surface, which confirms the existence of a temporary emersion (Fig. 7C-E).

\section{2. $31 \mathrm{~m}$ - thick bioturbated wackestone with intercalations of packstone and}

breccias. The wackestones yielded planktonic and benthic foraminifera as well as red algae. The packstones contain red algae, foraminifera, echinoids and green algae, with some beds organized into hummocky cross-stratification. Some patch reefs with several coral genera locally occur (Fig. 6D). The breccias consist of angular cm- sized debris of coral reef and bioclastic deposits. Planktonic foraminifera indicate that the lowermost part of this sedimentary unit was deposited during the late Serravallian-Tortonian, between 12.8 Ma and 8.2 Ma. Above, foraminiferal assemblages point to Zones N14 to N19 (Tortonian to possibly Zanclean, 11.6-3.8 Ma). The foraminifera in the uppermost part of the section point to Zone N19 and were deposited during the Zanclean, between 5.33 Ma and 3.8 Ma. The perireefal 
blocks of the breccias originated from two different sources: some developed laterally to patch reefs (Fig. 6D); others were eroded from the underlying late Burdigalian coral complex. Langhian to lower Serravallian deposits were not identified in St Martin, which could then indicate a depositional hiatus.

3. 1 to $\mathbf{3} \mathrm{m}$ - thick cross-bedded packstone with red algae and foraminifera, resting on a subaerial erosive surface (Fig. 6E). The foraminifera found in these deposits point to Zone N19 (Zanclean, 5.33-3.8 Ma).

In the southwestern part of St Martin, the Aquitanian-Burdigalian deposits comprise different depositional settings (Fig. 5). To the West (Terres Basses), we found high-angle dipping coral rubble beds overlain by low-angle dipping coral build-ups. This area is interpreted as the outer slope of a coral system, probably set up on the flanks of a late Oligocene subaerial volcano. In the Sabannah area, the occurrence of m- high patch reefs with branching colonies, planktonic and benthic foraminifera, is interpreted as a reef to foreef zone in an open sea (BouDagher-Fadel, 2008; Montaggioni and Braithwaite, 2009). At Mullet Bay, packstones with red algae and benthic foraminifera (amphisteginids and Asterigerina) and some coral beds and crossbedding occur, indicating inner-ramp, reefal deposits. In the Juliana Bay and Kool Hill sections, coral banks and benthic foraminiferal assemblages are indicative of a quiet lagoonal depositional environment (Andréïeff et al., 1988; Tucker and Wright, 1990; BouDagher-Fadel, 2008). To the east of St Martin, the data of Andréieff et al. (1987; 1988) indicate the presence of coral reefs at Pinel Islet and on islets east of Phillipsburg. As a result, St Martin was an island during the early Miocene, bordered by coral reef formations with lagoons to the southeast and fringing reefs to the northeast. Langhian deposits were not found, suggesting a possible middle Miocene emersion. Deposition of the upper SerravallianTortonian sediments of St Martin (Cupecoy) first occurred in a mid-outer-ramp environment above the Burdigalian reefal deposits indicated by abundant pelagic microfossils. These 
deposits change upward into mid to inner ramp settings with coral patch-reefs, and associated reefal breccias during the Messinian and the early Zanclean. Zanclean erosional surfaces affect the deposits, indicating a shallowing upward trend ending with an emergence. In this area, the occurrence of reworked breccias from Burdigalian reefal deposits testifies forindicates the permanence of emerged areas.

\subsubsection{Tintamarre}

At Tintamarre, the deposits are dominated by clayey limestones that yielded abundant macrofauna and larger benthic foraminifera dominated by Lepidocyclina, Miolepidocyclina, Miogypsina and Amphistegina associated with planktonic foraminifera. On the basis of six outcrops (Appendix E), the succession comprises, from bottom to top (Fig. 8):

1. $\mathbf{1 3}$ m- thick packstones with bivalves (oysters, Amusium, Chlamys), echinoids (Clypeaster and scutellids), larger benthic foraminifera, and some coral debris. The microfossils from the upper part of this unit correlate with the early part of Zone N8 (late Burdigalian);

2. $11 \mathrm{~m}$ - thick matrix-supported lower megabreccia with reefal to perireefal clasts (Appendix D; Fig. 9A). Clasts are $\mathrm{cm}$ to $\mathrm{m}$ - sized with blocks reaching $3 \mathrm{~m}$ wide, embedded into a lime wackestone matrix displaying slump structures and forereef-derived bioclasts (Clypeaster, larger benthic foraminifera, red algae, and molluscs). Reworked blocks do not display emersion features; 4. 0 to $\mathbf{4}$ m- thick brown clays with gypsum crystals. This facies, found only in the TINT 10 locality on the northern coast of the island laterally pinches on top of the megabreccia (Appendix D). The three previously described units are yellow to orange in the field, locally brown; 

mostly yielded bivalves (Amusium and other pectinids), echinoids (Clypeaster, scutellids), and benthic foraminifera. Packstones are unsorted, $\mathrm{mm}$ - to $\mathrm{cm}$ - grain-sized, debris-flows with well-preserved pieces of corals, red algae and molluscs. A hummocky cross-stratification is locally found into the packstones. The breccia is composed of $\mathrm{cm}$ - grain-sized reworked reefal to perireefal limestones. The succession is tilted to the SE below an erosional surface (Appendix E). The lower $19 \mathrm{~m}$ of the lithological succession is green and contains microfossils pointing to Zones N6-N8 (late Burdigalian, 18-15.97 Ma); the upper $14 \mathrm{~m}$ is white and microfossils point to Zones N8-N11 (Langhian, 15.9-13.6 Ma).

6. Up to 11 m- thick calcareous upper megabreccia (Fig. 10). This megabreccia rests unconformably on an erosional surface that transects previously tilted deposits (Appendix E).

It is composed of dm- to m- sized transported blocks of coral reef and associated bioclastic deposits and rafted red algae and coral limestone beds reaching several tens of meters long and up to $5 \mathrm{~m}$ - thick (Appendix E; Fig. 9A, B). The blocks are embedded into a white to pink wackestone matrix. The megabreccia is crosscut by shear zones and displays numerous soft reefal and red algal-coral rafted beds and clasts yielded benthic foraminiferal assemblages of Zones N5-N8a (latest Aquitanian-Burdigalian; e.g., samples CSM 42, 70 and 71; Appendix E). The matrix yielded planktonic foraminifera further indicating Zone N8b (early Langhian, 15.4-15 Ma). Consequently, the upper megabreccia deposited during the early Langhian and comprises reworked Burdigalian limestones.

In Tintamarre, Burdigalian to lower Langhian_deposits are dominated by clayey limestones that provided shallow-water fauna and debris flow interbeddings with transported corals. Two megabreccias with rafted beds and slumps also occur. The depositional setting is 
interpreted as an open sea, muddy forereef slope testified by abundant and well-preserved coral fragments (Fig. 8). During the late Burdigalian, however, lagoon conditions temporarily existed with the deposition of gypsum clays above the lower megabreccia. This indicates that the forereef slope depositional setting temporarily turned to shallower conditions then. The upper megabreccia comprises Burdigalian debris and rafts, which were emplaced in a muddy forereef environment during the early Langhian (15.4-15 Ma) (Appendix E; Fig. 9). This megabreccia unconformably lies upon southeastward tilted and eroded early Langhian beds. The blocks of the upper megabreccia do not display any emergence or tectonic features. This indicates that both their destabilization and transportation have occurred under submarine conditions, as classically seen in submarine active tectonic settings where large scale mass wasting is reported (e.g., Hine et al., 1992; Zachariasse et al., 2008; Dailey et al., 2019). The upper megabreccia was transported towards the ESE to SE, indicating that it originated from the WNW to NW in the submerged part of the Burdigalian reefal platform of Anguilla. One way to explain this arrangement is to consider that normal faults trending NE-SW and deeping NW occurred at that time between Anguilla and St Martin, this type of fault having been identified in the southwestern part of St Martin (Legendre, 2018).

\subsubsection{Barbuda}

The Highland Fm. comprises a 30 m- thick carbonate succession. The lower part of the formation does not crop out. From bottom to top we identified (Appendix F):

1. $\quad 4.5 \mathrm{~m}$ - thick grainstones with isolated massive, coral colonies. Corals are dominated by Montastraea and Porites. The sediments yielded benthic foraminifera (Miarchaias, and Amphistegina) pointing to the late Miocene;

2. $9 \mathrm{~m}$ - thick red algal and larger benthic foraminifera-rich wackestones to packstones; 

planktonic foraminifera (Neogloboquadrina acostaensis, Sphaeroidinellopsis subdehiscens, and Globorotalia margaritae) indicative of a Zanclean age;

513

\section{4. $\mathbf{1 2 . 5} \mathrm{m}$ - thick red algal wackestones to packstones with benthic and planktonic}

foraminifera. The uppermost part of the succession is severely weathered. Planktonic foraminifera indicate that the lower and upper parts of the unit was deposited during the Zanclean and between the Zanclean and Piacenzan, respectively.

In Barbuda, benthic foraminifera are dominated by amphisteginids. Mud and planktonic foraminifera occur throughout the section. Corals are documented as isolated, and consist of massive colonies in life position. Consequently, the depositional environment is interpreted as an open-sea, shallow water reefal to forereef muddy carbonate platform or ramp deposited in low-energy conditions. These results are in agreement with those of Brasier and Donahue (1985), who estimated a palaeobathymetry of $c a 40-50 \mathrm{~m}$. The middle part of the section is dominated by planktonic foraminifera facies devoid of corals, indicating a deeper environment of deposition than the lower and upper parts of the section. This suggests that the succession has recorded a regressive-transgressive cycle (Appendix F). During the late Miocene-Zanclean interval (samples BAR 1 to 9; Appendix F), the depositional environment changes from reefal inner-ramp ( $c$ a $10-20 \mathrm{~m}$ palaeodepth) to outer-ramp ( $c a 40-50 \mathrm{~m}$ paleodepth). The maximum palaeodepth is reached between samples BAR 9 and 13 and occurred during the Zanclean, when wackestones with abundant planktonic foraminifera were deposited. Above, outer-ramp environment changes into mid-ramp during the ZancleanPiacenzan (?), thereby indicating a moderate regressive trend.

\subsubsection{Antigua}

The lowest marine limestone beds of the Antigua Fm. yielded Rupelian foraminifera (Eulepidina undosa, Lepidocyclina (L.) yurnagunensis) (Appendix G), while the limestones 
above them contained Chattian foraminifera (Lepidocyclina (Lepidocyclina) yurnagunensis, L. (Nephrolepidina) braziliana, Heterostegina israelskyi, and Neorotalia sp.) (e.g., Pares cross-section; Appendix G,). Consequently, the Antigua Fm. is likely to have been deposited between the Rupelian and the Chattian.

In Antigua, the Central Plain Group was deposited into lakes and coastal lagoons, as previously documented (e.g., Martin-Kayes, 1959; Frost and Weiss, 1979; Donovan et al., 2014). Above, the Antigua Fm. was deposited along a low-angle northeastward dipping carbonate ramp, with inner-ramp, reefal environments in the southwest changing northeastwardly into a mid-ramp depositional setting characterized by abundant planktonic foraminifera. These results are in agreement with the regional sedimentary organisation proposed by Martin-Kaye (1969).

\subsection{Offshore}

The profiles GA 11, GA 15, ANT019-24, CPEM 302, CPEM 509 and CPEM 510 are used to compare onshore data with offshore ones because: 1) GA 15 intersects the seismic profile C2 of the Saba Bank petroleum prospect, which was calibrated using wells SBD1 and SBD2 (Matchette-Downes, 2007); 2) GA 11 allows following seismic sequences to the north across the Kalinago Basin; 3) ANT019-24 allows investigating the northwestern margin of the Anguilla Bank; 4) CPEM 302 provides information about the southern part of the Anguilla Bank and allows correlations with the southern part of the Kalinago Basin; and 5) CPEM 509 and CPEM 510 illustrate the seismic stratigraphy of the Antigua Bank. In addition, the northern ends of lines GA 08 and GA 09 are only $5 \mathrm{~km}$ away from the island of St Martin (Appendix J), 213A was performed on the Anguilla Bank south of St Barthélemy (Appendix J), and 509-510 are located in the vicinity of the island of Antigua, allowing onshore-offshore correlations. 


\subsubsection{Seismic sequences}

We identified seven seismic megasequences bounded by regional prominent

563

564

565

566

567

568

569

570

571

572

573

574

575

576

577

578

unconformities and their correlative conformities (Vail et al., 1977; van Wagoner et al., 1988;

Cattuneanu, 2006) over the whole investigated area (MS1 to MS7). The most complete succession is best exemplified south of the Saba Bank, along crossing lines GA 15 (ENEWSW; Fig.10A) and Saba Bank C2 (NW-SE; Fig. 10B). The C2 line was reinterpreted and a seismic pattern partly similar to that of Church and Allison (2004) was found, thereby allowing chronostratigraphic assignments to the megasequences. From bottom to top they are:

- Megasequence 1 (MS1): it comprises poorly-defined, chaotic reflectors, locally overlaid by low to very low frequency, discontinuous reflectors. Transparent facies also occur. The top of the sequence is an erosional unconformity termed SB1 usually underlined by a strong amplitude reflection. In wells SBD1 and SBD2, MS1 is overlaid by a subaerial andesitic lava flow that occurred during the late Eocene (38.1-35.9 Ma interval; Church and Allison, 1984). MS1 is found on the GARANTI and ANTITHESIS lines (Figs. 10 to 12; Appendix J) and on the CPEM lines, especially in the southern part of the Kalinago Basin (Fig. 13).

No accurate information about MS1 is available yet. Nevertheless, reworked Cretaceous and Paleocene microfossils have been found in the overlying megasequence MS3, suggesting that MS1 is partly made of sedimentary rocks of these ages.

- Megasequence 2 (MS2): it comprises seismic units displaying inverted half-graben structures with faint and subparallel to fan-shaped reflectors (Fig. 10A and B). In some cases, it is organized into fan-shaped reflectors draping underlying topographic highs and thickening downward (Fig. 11A; 12). The half-grabens are visible on NE-SW profiles (fig. 10B) and not on NW-SE profiles (Fig.10A), suggesting that their orientation is overall NW-SE. MS2 has not been reached by the drillings. The top of MS2 is the irregular, erosional, newly defined 
surface SB2 found extended below the late Eocene subaerial andesite drilled in the Saba Bank (Church and Allison, 1984). MS2 has not been recognized in the southern part of the Kalinago Basin (Fig. 13). MS2 probably consists of sedimentary deposits lying unconformably on MS1 (Figs. 10A, 11A). It underwent a late mid-Eocene compression leading to inversion of half grabens (Philippon et al., 2020a).

- Megasequence 3 (MS3): it comprises up to 2.5 second two-way travel-time (stwtt)- thick deposits. MS3 is characterized by discontinuous to continuous reflectors of low amplitude, medium to high frequency, always sub-parallel and well stratified, locally prograding (Fig. 10). MS3 onlaps above SB2 and seals the compressive deformations in MS2. It is marked by an abrupt change in seismic facies that evolves from continuous well-bedded reflectors, lowangle truncations in MS2 to onlaps in MS3. The top of the sequence is covered by an unconformity hereafter named SB3. MS3 was not identified in the southern part of the Kalinago Basin (Fig. 13).

In the northern part of the Kalinago Basin, MS3 displays regular, mid-amplitude and parallel reflectors (Fig. 10) that progressively pinch against spurs (Fig. 10A, 11A). On lines GA-08 and 09, MS3 displays prograding beds on the southern margin of the Anguilla Bank, a pattern that is also found on lines ANT 19 and 24 (Fig. 11B; Appendix J). These prograding beds are related to downslope detritus originating from the topographic highs. Along the flanks of the spurs, the beds of MS3 are organised into fans mimicking the shape of the relief and down-lapping above unconformity SB2, controlled by NW-SE trending syn-sedimentary faults (Figs. 11A and 13; Appendix J). On the Walichi Flat, south-southwestward prograding beds develop above the basement (Fig. 12B). Offshore in the Antigua Bank and the southern part of the Kalinago Basin, MS3 is missing (Fig. 14). Onshore, continental deposits are recorded (Central Plain Group of Antigua). These observations indicate that the Kalinago Basin was not extending in this area (Fig. 13). Consequently, MS3 has been deposited into 
sub-basins separated by topographic highs. As no recent fault was evidenced on the margins of the Kalinago Basin, the difference of elevation between the top of the Anguilla Bank and the MS3 deposits of the Kalinago Basin varies between 1,000 to 1,500 m, broadly reflecting the palaeobathymetry of the deep parts of the basin. Such a difference in elevation is also found in the southeastern part of the Saba Bank (Fig. 10).

In summary, MS3 unconformably resting upon the erosional surface SB2 is characterised by high relief changes with topographic highs (Walichi Flat, Saba Bank, and spurs) and newly-formed depocentres controlled by synsedimentary normal faults (northern Kalinago Basin).

- Megasequence 4 (MS4): it comprises up to 2.5 stwtt- thick gently-dipping reflectors, locally organized into low angle inclined prograding units (Figs. 10 to 12). Onlaps are present against paleoreliefs (Appendix J). The sequence ends with an erosional surface termed SB4 that truncates the underlying reflectors. Locally, low angle reflectors of the overlying megasequence onlap onto SB4. Opposite to MS3, MS4 occurs regionally, from the Kalinago Basin in the NW (Figs. 11, 12) to the Antigua Bank in the SE (Fig. 13).

Northeast of Saba Bank, deposition of MS4 is controlled by synsedimentary faults in the NW-SE direction. (Fig. 11A). Southeast of the Saba Bank, MS4 displays parallel bedding (Fig. 10) or fans (Fig. 11A), above the unconformity SB3. In the vicinity of the submarine spurs (Anguillita, Southeastern seamounts) and highs (Saba Bank, Anguilla Bank, and Walichi Flat), SB3 is erosional with toplaps in the underlying MS3 and onlaps in the overlying MS4 (Figs, 10, 11, 13; Appendix J). In the southern part of the Kalinago Basin and Antigua Bank, MS4 directly overlies MS1. Consequently, MS4 is deposited on a topographic surface SB3 which is erosional, except in the deepest parts of the depressions. SB3 exhibits an erosive character over $\mathrm{ca} 500 \mathrm{~m}$ vertical drop at maximum, and consequently sedimentation in troughs occurred at several hundred meters depth. 
- Megasequence 5 (MS5): it reaches 1 stwtt- thick and comprises medium to strong amplitude, medium frequency, parallel continuous reflectors. The sequence shows an aggrading pattern and retrogrades on older reliefs. The top of MS5 is characterised by an unconformity termed SB5. SB5 is either erosional (Fig. 10A, northern part) or bedding is subparallel with low-angle onlaps above (Fig. 10B, Saba Bank). MS5 is found from the Kalinago Basin in the NW (Fig. 11, 12) to the Antigua Bank in the SE (Fig. 13).

In the Kalinago Basin, South of the Saba Bank, Walichi Flat and Antigua Bank, MS5 is organised into parallel reflectors mostly parallel to MS4 reflectors. Onlaps are found in the vicinity of submarine highs, above SB4. The latter displays clear erosional features on the spurs, on the margin of the Anguilla Bank, on the Walichi Flat and on the uppermost part of the Saba Bank (Figs. 10, 11, 12). Consequently, SB4 is interpreted as a subaerial structure developed on submarine highs, that is confirmed by the analysis of the dredged GA 03 rocksamples collected on the southeastern spur (Fig. 2; Appendix I; see below). Erosion is found over a few hundred meters depths at maximum, suggesting that deposition of MS5 occurred at several hundred-metres depth in basin areas.

- Megasequence 6 (MS6): it reaches 0.5 stwtt- thick and comprises medium- to strongamplitude, medium-frequency, continuous and parallel reflectors and prograding reflectors. On the Saba Bank, reflectors are parallel and strongly reflective (Figs. 10, 11), like on the Anguilla Bank and the Antigua Bank (Fig. 13). In the southern part of the Kalinago Basin, MS5 is locally overlain by an erosional surface termed SB6.

- Megasequence 7 (MS7): it is distinguishable in the southern part of the Kalinago Basin and Antigua Bank on CPEM seismic lines (Figs. 2, 13). It comprises medium- to strongamplitude, medium-frequency, continuous and parallel reflectors which locally display fan shaped structures. In the northern part of the investigated area, SB6 is parallel to reflectors 
659

660

661

662

663

664

665

666

667

668

669

670

671

672

673

674

675

676

677

678

679

680

681

682

683

and both MS6 and MS7 are often indistinguishable. Consequently, they are grouped into a MS6+MS7 megasequence (Fig. 10).

In most of the investigated area, deposits of MS6 and MS7 conformably cap those of MS5. Erosional features are found in the vicinity of spurs (Anguillita and Martinita seamounts) and on Walichi Flat where SB5 displays truncations of the underlying MS5 (Fig. 11). Discrete onlaps of fan-shaped reflectors of MS7 above SB6 are found in the southern part of the Kalinago Basin, partly related to the synsedimentary activity of recent normal faults (Fig. 13).

\subsubsection{GARANTI dredged samples}

Dredged samples have been collected on the flanks of seamounts in the northwestern part of the Kalinago Basin and are localized on seismic profiles to allow calibrating the seismic stratigraphy (Fig. 2): DR GA-04-01 and DR GA-04-02 are located on the seismic profile GA11 and DR GA-03-01 on GA13.

Dredge DR GA-04-01 (Fig. 11), in MS6, yielded bioclastic wackestones to packstones with red algae and benthic foraminifera. Larger benthic foraminiferal assemblages in these samples correlate with the planktonic foraminiferal zones N14-N18, thus indicating a late Miocene age of deposition (Appendix I).

Dredge DR GA-04-02 (Fig. 11), in MS6, yielded wackestones and packstones with planktonic foraminifera. One sample point to Zones N18-N19 (latest Messinian-Zanclean, 5.8-3.8 Ma), when another points to Zone N19 (Zanclean, 5.33-3.6 Ma). The wackestones with planktonic foraminifera are bored and borings are infilled with likely modern muds containing planktonic foraminifera of Zones N22-N23 (Calabrian-Holocene).

Dredge GA-03-01 in MS5 yielded packstones with red algae and foraminifera pointing to Zones N12b-N20a (Serravallian-Zanclean). The packstones have suffered from 
687

microsparitization and are crosscut by opened fractures infilled with wackestones enriched in planktonic foraminifera and reworked microsparitized red algal packstones (Appendix I). The foraminifera found within the wackestones infillings point to Zone N19 (Zanclean).

\subsection{Age model}

\subsubsection{Onshore}

In the Anguilla Bank, the synthetic lithostratigraphical succession of each island can be reconstructed and correlated based on our new biostratigraphic data and field investigations (Fig. 14). In the three islands of the Anguilla Bank, the age of the lower part of the Neogene reefal deposits ranges between the (late?) Aquitanian and the Burdigalian. This age is consistent with i) our new radiometric data at $c a$ 25-24 Ma (latest Oligocene) of the andesitic boulder from submarine lahar deposits found below the carbonate platform in St Martin (Appendix K) and ii) that of a subaerial lava flow found in St Barthélemy in a similar setting (Legendre et al., 2018; Cornée et al., 2020) (Appendices G and H). Middle Miocene (Langhian-Serravallian) deposits occur in Anguilla and Tintamarre, but they are missing in St Martin where an erosional unconformity is strongly suspected to have occurred between the Burdigalian and the uppermost Serravallian-Tortonian deposits. However, outcrop conditions did not allow direct observation of this surface. Late Miocene (Tortonian-Messinian) sediments were found in St Martin and Anguilla. In Tintamarre, they may have deposited, but were probably removed by erosion. Zanclean deposits have been identified in St Martin where theyare transected by erosional surfaces.

In the Antigua Bank and Barbuda, the Highland Fm. encompasses the late MiocenePiacenzan interval at youngest (Appendix F). Neither unconformity nor major facies change 
were found between the upper Miocene deposits (samples BAR 1 to BAR 7) and the overlying Zanclean ones. Consequently, a latest Miocene age is considered here (Messinian) for the lower part of the Highland Fm. In Antigua, sediments of the Central Plain Group deposited during the Rupelian (because they are located below the Antigua Fm.), and those of the Antigua Fm. deposited between the Rupelian and the Chattian (Appendix G).

\subsubsection{Offshore-onshore correlations}

Age calibration of offshore sequences and unconformities takes into account the calibration of line C2 with Saba Bank wells, correlations through seismic sequences and unconformities, and dredges data from the GARANTI and other cruises (Fig. 2). These combined data allow calibrating the seismic stratigraphy, correlating onshore and offshore sequences and concur to constrain a late Eocene-Pleistocene age range for the deposits of the Anguilla Bank, Antigua Bank, and Kalinago Basin (Fig. 15).

- MS1: it correlates with the acoustic basement overlain by a subaerial andesitic complex or MS2. The only chronostratigraphic data available indicate ages ranging between 38.7 Ma and 30.8 Ma (Priabonian-Rupelian) in the Saba Bank wells (Church and Allison, 2004; Matchette-Downs, 2007). The wells did not reach nor MS1 neither MS2 but yielded reworked Cretaceous and Paleocene microfossils in the sequences overlying the subaerial andesitic complex. Following Jany et al. (1990) and Church and Allison (2004), MS1 is considered to have been deposited between the Late Cretaceous and the middle Eocene.

- MS2: this locally folded unit (Philippon et al., 2020a) (Fig. 10A) was previously included into the acoustic basement of Church and Allison (2004). It is located between the basement and the Priabonian-Rupelian andesites of wells SBD1 and SBD2, and the overlying megasequence MS3 dating from the late Eocene-early Oligocene. On land at St Barthélemy, compressive structures affecting middle Eocene carbonate deposits (Cornée et al., 2020) have 
been estimated to have occurred during the late middle-Eocene (Philippon et al., 2020a).

735 Consequently, MS2 and SB2 are assigned to the early middle-Eocene.

736

737

738

- MS3: it corresponds to the "Lower Carbonate Unit" and the "Channel Turbidite Unit" of Church and Allison (2004) identified on the re-interpreted profile C2 (Fig. 10B). Based on foraminiferal data, the "Lower Carbonate Unit" points to the late Eocene in well SBD1. Based on calcareous nannofossils, the "Channel Turbidite Unit" has been dated to the late Eoceneearly Oligocene interval in well SBD2 (Church and Allison, 2004). Consequently, MS3 has an age ranging from the late Eocene to the early Oligocene.

- MS4: it corresponds to the "Fluvial Deltaic Unit" of Church and Allison (2004) on profile C2 (Fig. 11). This unit yielded microfossils ranging in age from the late Oligocene to the early Miocene (Church and Allison, 2004). On profile GA 08, MS4 can be traced to $5 \mathrm{~km}$ off St Martin (Fig. 2; Appendix J). There, MS4 displays progradations and chaotic reflectors. Onshore in St Martin, the margin of the early Miocene carbonate platform is marked by forereef slope deposits which exhibit high dip. (Fig. 6A-B). Moreover, an Oligocene subaerial unconformity was also found in St Martin (Andréïeff et al., 1988; this work) and St Barthélemy (Cornée et al., 2020), between late Eocene and early Miocene deposits. In the Antigua Bank, MS4 partly correlates with the Rupelian-Chattian Oligocene Antigua Fm. Consequently, MS4 deposited during the late Oligocene-early Miocene interval, and the underlying unconformity SB3 is Oligocene.

- MS5: it corresponds to the lower part of the Upper Carbonate Unit. Foraminifera and calcareous nannofossils indicate that its lower part is not younger than the early Serravallian and its upper part Zanclean at youngest (Church and Allison, 2004). The basal unconformity SB4 is assigned to the middle Miocene and can be traced up to the margin of the Anguilla Bank (lines CPEM 302, GA 08, GA 09; Appendix J). Onshore in St Martin and Tintamarre, this middle Miocene (Langhian) unconformity also occurs, and is overlaid by late Serravallian 
to Zanclean deposits (Fig. 14). In V-shaped basins eastward in the forearc, Boucard et al. (2021) also described a regional erosional unconformity UB2 between early and middle Miocene sedimentary units. Consequently, MS5 is assigned to the middle-late Miocene and the underlying SB4 unconformity was possibly emplaced during the Langhian.

- MS6: it corresponds to the upper part of the "Upper Carbonate Unit" of Church and Allison (2004). In the Saba Bank wells, this sequence provided bioclastic coral-dominated deposits covering a red-algal dominated platform. MS6 rests on the erosional unconformity SB5, which corresponds to the base of the reefal deposits still remaining undated. The hauldredges carried out during the cruise GARANTI on the Martinita and Southeastern seamounts within MS5 and MS6 (Figs. 2 and 11), yielded upper Miocene and lower Pliocene limestones (DR GA 03-01, 04-01, and 04-02; Appendix I). Because microsparitization is found in the upper Miocene limestones, which are also affected by open fractures infilled with Zanclean deposits, we conclude that the Martinita and Southeastern seamounts emerged during the latest Miocene at oldest, and that they subsequently started drowning during the Zanclean. This emersion could relate to SB5. Moreover, the lower Pliocene limestones at site DR-04-02 exhibit borings that may indicate that the seamounts were very near sea level or emergent during the Piacenzan-Gelasian interval and were drowned by the Calabrian. These borings could relate to SB6 unconformity. In St Martin, erosional unconformities are found in lower Zanclean deposits (Fig. 6E). In the Guadeloupe Archipelago ( $c$ a $250 \mathrm{~km}$ further south), there is a shallow water carbonate platform that was deposited above a major, latest Miocene to early Pliocene, erosional unconformity (Cornée et al., 2012; Münch et al., 2014; De Min et al., 2015). Red algae-rich deposits dominate in its lower part (Zanclean-Gelasian), and gradually change upwards to coral-dominated deposits (Gelasian-Calabrian). This succession is similar to MS6 in Saba Bank wells. In the Antigua Bank, MS6 was also partly correlated with the Zanclean-Calabrian deposits recovered from the IODP leg 340 (Legendre, 2018). 
Consequently, the underlying SB5 unconformity is confidently assigned to the latest Miocene-early Pliocene, and MS6 to the early Pleistocene.

- MS7: it mainly occurs in the southern part of the Kalinago Basin where it is thick enough to be identified on seismic profiles. The wells recovered from IODP 340 indicate a Calabrian (1 Ma) to Holocene age (Coussens et al., 2012). In the northern part of the Kalinago area, MS7 remains thin and was grouped with MS6.

In summary, offshore and onshore data allow us to date the Cenozoic deposits in the northern Lesser Antilles, assigning ages to the regional unconformities and estimating the duration of their corresponding hiatuses (Fig. 15): SB1 was emplaced during the Paleocene to middle Eocene ; SB2 during the late Eocene; SB3 during the Oligocene; SB4 during the middle Miocene (Langhian); SB5 during the latest Miocene-early Pliocene; and SB6 during the early Pleistocene.

\subsection{Palaeogeographical evolution}

Using our dataset that combines onshore and offshore investigations and correlations, we are able to propose novel palaeogeographical maps of the Northern Lesser Antilles (Fig. 16). Sequence boundaries on seismic lines were considered subaerial when regional erosional features were observed, with the following criteria: clearly-identified toplaps and onlaps below and above the unconformities, respectively.

During the Eocene, the Anegada Passage did not exist (Jany et al., 1990; Mauffret and Jany, 1990). The upper Eocene SB2 unconformity, following an upper Eocene compression (Philippon et al., 2020a), is regionally erosive. MS2 is only preserved as relict patches in the northern part of the Kalinago Basin, Saba Bank and Anguilla Bank, suggesting that SB2 is the expression of a general emersion. The emerged area was extended from the Saba Bank to the Antigua Bank, for at least $300 \mathrm{~km}$, and was connected to Puerto Rico (GraNoLa landmass of 
Philippon et al., 2020a). In the Anguilla Bank, late Eocene sedimentation resumed after SB2, linked to volcanic activity in St Barthélemy.

During the latest Eocene-early Oligocene (MS3) ( $c a$ 38-28 Ma), to the north of the studied area, a major extensional episode occurred along NW-SE trending faults. The Kalinago Basin opened and the sea invaded the depressions despite the sea level drop of about a hundred meters that occurred at the Eocene-Oligocene transition (Miller et al., 2020). The Saba, Anguilla and Antigua banks and the Walichi Flat remained all above sea level in the footwall of normal faults. At that time, volcanism was active in Antigua, St Martin and St Barthélemy islands, and in Saba Bank (Fig. 16B).

During the late Oligocene (SB3) (28-23 Ma), the rifting propagated southward and the Kalinago Basin deepened. Its eastern and western shoulders were uplifted and became emergent in the Saba Bank and from Antigua to the Walichi Flat (Fig. 16C). Onshore, this emergence is clearly recorded: in St Martin, subaerial upper Oligocene volcanism is now proven and Aquitanian reefs developed onto tilted and eroded Eocene sediments (Andréïeff et al., 1988; this study); in St Barthélemy, an erosional surface crosscutting the upper Eocene deposits is capped by upper Oligocene subaerial lavas (Cornée et al., 2020); in Antigua, the Rupelian Central Plain Fm. was deposited in an inland paleoenvironmental setting, then the sea invaded the island during the Rupelian and the Chattian.

During the latest Oligocene-early Miocene (MS4) (24-16 Ma), only small islands remained above sea-level, despite hundred meters sea level drops, indicating a significant and general subsidence (Fig. 16D). The now drowned but previously emerged area extending from Antigua to Anguilla was then capped by reefal carbonate deposits delineated by steep slopes and their associated deposits. Elsewhere, basin sediments were deposited. Some tectonic activity is recorded in the Anguilla Bank with mass wasting and synsedimentary normal faults in St Martin (Legendre, 2018; this study). A subaerial volcanic activity is 
evidenced in St Barthélemy and Antigua. Offshore, MS4 infilled depressions or fringes spurs, indicating regional subsidence. Fault activity is recorded only to the north of the study area, on the southern margin of the Walichi flat, in the Kalinago Basin. In the forearc to the east of the Anguilla Bank, steep NE-SW trending fault controlled basins opening (V-shaped basins, Boucart et al. (2021)) (Fig. 1B) (St Barthélemy and Antigua valleys). NW-SE and their conjugated NE-SW trending normal faults were sealed by MS5 (Fig. 10A). In St Martin, the upper Oligocene pluton and its country rock are tilted along NE-SW trending faults (Legendre, 2018). In Anguilla, the Eocene beds were tilted to the SE and capped by a subhorizontal Miocene carbonate platform, suggesting that the tilt was also controlled by this set of NE-SW trending faults. Consequently, moderate fault activity is found only in the northern part of the investigated area, at the vicinity of the Anegada Trough, which probably started to open.

At St Martin in the Juliana airport section (Appendix D), E-W trending synsedimentary normal faults affected the upper Burdigalian lagoonal deposits. These faults display dip-slip kinematics indicating a NNE-SSW extension (Fig. 7) (Legendre, 2018; Noury et al., 2018). Such an orientation is consistent with the Kalinago rift trend. Local uplifts have been recorded during this tectonic episode, at Juliana and Kool Hill, with the occurrence of karstic features (Appendix D). In Tintamarre, the lower megabreccia also was deposited during the late Burdigalian (Fig. 9; Appendix E), and it was likely coeval with the deposition of lagoonal sediments indicative of a temporary uplift (Fig. 14). Consequently, the emplacement of the lower megabreccia is most related to observed strain affecting the Juliana section, both indicating moderate N-S to NNE-SSW extension (i.e. parallel to the trench extension) in this area between $18 \mathrm{Ma}$ and $16 \mathrm{Ma}$.

During the early Langhian (SB4) (15.4-15 Ma), the sea level rose by $80 \mathrm{~m}$ (Miocene climatic optimum; Miller et al., 2020; Westerhold et al., 2020). Large islands, however, 
emerged and shallow banks were deposited. This indicates that another significant uplift event occurred, which was most probably controlled by NE-SW faults that tend to be parallel to the Anegada Trough (Fig. 16E). Antigua, southern Anguilla and Saba Banks became emergent whilst the northern Anguilla Bank remained under shallow waters. Elsewhere, basin sediments have been deposited. East of Anguilla Bank, the spurs separating the V-shaped paleovalleys emerged during the early-middle Miocene and underwent erosion (Boucard et al., 2021). Volcanic activity is not recorded onshore neither offshore.

Between the middle Miocene and the early Pliocene (MS5) (ca 15-4 Ma), a new regional drowning occurred and only small islands were emergent (St Barthélemy and St Martin) (Fig. 16F). From Anguilla to Antigua, shallow water reefal platforms have formed whilst basin deposits occurred elsewhere and the V- shaped basin did not operate anymore (Boucard et al., 2021). On the southern margin of the Anguilla Bank, MS5 locally display chaotic reflectors that could indicate slope deposits (Fig. 13B).

During the latest Messinian-early Zanclean (SB5) ( $c$ a 6-4 Ma), the sea level rose by 20 m (Miller et al., 2020) but new islands appeared, indicating a regional uplift (Fig. 16G). These new islands, fringed by shallow-water carbonate deposits, emerged from Anguilla to Antigua and shallow-water reefal deposits were emplaced on the Saba Bank. The volcanic islands of the present-day volcanic arc began to emerge by the Pliocene in northwest St Eustatius and southeast St Kitts (e.g., MacDonald et al., 2000). Elsewhere, basin deposits are observed.

During the Zanclean-Calabrian (MS6) (4-1 Ma), glacio-eustatic sea level variations could reach $90 \mathrm{~m}$ (Miller et al., 2020). The present-day physiography of the northern Lesser Antilles was mostly acquired (Fig. 16H). A regional drowning has however occurred, of greater amplitude than sea level variations, since only small islands remained emerged ( $\mathrm{St}$ Martin, St Barthélemy, Anguilla, and Antigua). Eastward in the forearc, a drastic subsidence occurred and is likely to be related to margin basal and frontal subduction erosion, which 
probably accounts for the retreat of the volcanic arc westward (Boucard et al., 2021). Contemporaneously, the volcanic islands of the recent arc emerged, extending from Montserrat to Saba. Discrete synsedimentary faulting is recorded in the southern part of the Kalinago Basin. On the Antigua, Anguilla and Saba Banks, reefal and red algal platforms were emplaced.

During the middle and late Pleistocene, several glaciations occurred, coinciding with recurrent up-to-ca 120 m- drops in global sea level (e.g., during Marine Isotopic Stages 16a, 12a, 10a, 6a, and 2 [at 0.63, 0.44, 0.34, 0.14, and 0.03 Ma, respectively]; Railsback et al., 2015; Miller et al., 2020; Westerhold et al., 2020) (Fig. 16I). Evidence of emersion has been found in carbonate submarines banks, such as Saba Bank, where giant sinkholes, several hundred meters deep, have been recently revealed (van Duyl and Meesters, 2018). These drops had direct consequences on the emerged areas and relationships between the northern Lesser Antilles islands.

\subsection{Geodynamic settings since the late Eocene}

The strain pattern observed in this study reflects the accommodation of trench bending that followed a plate boundary rearrangement at the northeastern corner of the Caribbean Plate, which originated both from collision between the Bahamas Bank and Greater Arc of the Caribbean with along its northern boundary and a major change in plate kinematics (Boschman et al., 2014; Legendre et al., 2018; Philippon et al., 2020a, b; Boucard et al., 2021). Our palaeogeographical reconstructions (Fig. 16) allow, for the first time, to evidence regional scale vertical motions affecting the whole northern Lesser Antilles. Indeed, we show the emergence of hundreds $\mathrm{km}$ - long landmasses along the trench in the arc area and subsequent regional drownings of these lands at the scale of tens Myrs. 

(Philippon et al., 2020a), which led to large emerged areas in the northern Lesser Antilles, the tectonic regime changed drastically. Since then, the palaeogeography has been controlled by regional extensional setting leading to alternating episodes of uplift and subsidence. Vertical motions are controlled by two sets of normal faults trending NE-SW and NW-SE, respectively. The Kalinago Basin opened during the late Eocene-early Oligocene and propagated from north to south, between $\sim 34$ and $\sim 28 \mathrm{Ma}$, in intra-arc rift position (MS3). First, this opening was controlled by NW-SE trending normal faults, i.e. parallel-to-thetrench. Later on, NW-SE and NE-SW trending regional normal faults affected the northern Lesser Antilles realm (MS3 and MS4) (Jany et al., 1990; Legendre et al., 2018; Boucard et al., 2021; this work). Consistently, NE-SW-trending faults fractured the inner forearc generating deep V-shapes valleys separated by shallow crustal spurs (Boucard et al., 2021). This regional extension in the upper plate possibly resulted from the Bahamas Bank collision and westward drifting, the consecutive margin convex bending and crustal blocks rotations (Mann et al., 2005; Philippon et al., 2020b). This extension might also be consistent with a transient trench rollback (over a short time lapse) during the early stages of extension. Soon after SB3 (late Oligocene erosional surface), the zone of maximum subsidence switched eastward to the forearc, on the eastern margin of the Kalinago Basin where the V-shaped deep basins and Spurs opened during the late Oligocene-early Miocene (Boucard et al., 2021). Volcanism remained active from Antigua to St Barthélemy, and ceased at ca 24 Ma in St Barthélemy and St Martin.

Between SB4 and SB5 (middle Miocene-early Pliocene) the deformation regime changed. The tectonic activity along the NE-SW faults, which bound the V-shaped basins, has progressively ceased and deep NW-SE faults resulted from an extensive deformation normal to the margin. A significant subsidence affected the forearc and the Kalinago basin. The 
volcanic arc migrated westward into the arc interior. The margin has likely undergone a longterm frontal erosion compared to the accretionary Central and Southern Lesser Antilles. This frontal erosion, trench landward migration associated with margin extension, fracturing, drastic subsidence and volcanic arc landward retreat testify for enhanced basal erosion of the upper plate (Boucard et al., 2021).

\subsection{Faunal dispersals}

Our results indicate that prominent uplift events occurred during the late Bartonianearly Priabonian, the Chattian, the Langhian and the early Zanclean in the northern Lesser Antilles. During these intervals, hundred kilometers- long and wide emerged islands extended from Antigua to the Anguilla and Saba Banks (Fig. 16), thus providing more or less continuous terrestrial connections to the Greater Antilles (Puerto Rico and Virgin Islands). Such a connection has been previously proposed but only for the late Eocene (GrANoLA land, Philippon et al., 2020). Whereas it has been unsuspected until now, with this thorough geological and geophysical study of the Northern Lesser Antilles realm, we evidence that the northern part of the Lesser Antilles has been a favourable area that may have allowed the dispersal of terrestrial species between the Greater Antilles and the northern part of South America, not only during the late Eocene but also from the Oligocene to recent times with the episodic formation of emerged archipelagos. Moreover, this potential transit zone identified here, from the Anguilla Bank to the Antigua Bank, can be extended southwards to the Guadeloupe archipelago where, there too, vast island areas have been identified with a similar schedule: at the early Miocene-middle Miocene transition, at the late Miocene-early Pliocene transition and during the Early Pleistocene (De Min, 2014; De Min et al., 2015), aside from Pleistocene sea-level drops controlled by glaciation (Railsback et al., 2015). Thus, the northern Lesser Antilles might have contributed to faunal dispersals at multiple times since 
the late Eocene. During the late Eocene, the emerged areas in the northern Lesser Antilles were at their maximum and might have been connected to the supposed GAARlandia land bridge, playing a role in the dispersal of South American terrestrial fauna to the Greater Antilles (Iturralde-Vinent and McPhee, 1999). However, later dispersal events have also been evidenced (Fabre et al., 2014; Brace et al., 2015; Courcelle et al., 2019) and they may be supported by the repeated occurrence of more or less important emerged land masses in the northern Lesser Antilles (this work) and possibly in the southern Lesser Antilles, too. The role of the Lesser Antilles in the dispersal of land fauna during the last 40 Myrs must therefore be reassessed, on one hand by searching for a terrestrial fossil record that is currently lacking, and on the other hand by reconstructing the palaeogeography of its southern part between Guadeloupe and Venezuela.

\section{CONCLUSIONS}

Our integrated onshore-offshore study of the Cenozoic deposits of the northern part of the Lesser Antilles shows:

- An isolated reefal platform in Anguilla lasting the whole Aquitanian to Messinian interval (23-ca 5.3 Ma); reefal to peri-reefal deposits fringing an island in St Martin and covering the Aquitanian-Zanclean interval (23-3.8 Ma); peri-reefal to slope deposits at Tintamarre with two episodes of mass wasting, which occurred during the late Burdigalian (18-16 Ma) and the early Langhian (15.4-15 Ma), respectively; reefal deposits at Barbuda from the Messinian-Piacenzan(?) (?11.6-?2.5Ma); reefal then deep sea deposits in Antigua spanning the Rupelian-Chattian interval (?33.9-23 Ma).

- Offshore, we defined seven seismic megasequences (MS) bounded by regional-scale, erosional unconformities. MS1 corresponds to a partly sedimentary Cretaceous to 
lower Eocene deformed basement; MS2 is a middle-upper Eocene sequence displaying inverted grabens; MS3 deposited during the late Eocene and the early Oligocene; MS4 deposited between the late Oligocene and the early Miocene; MS5 deposited between the middle Miocene and the early Pliocene; MS6 and MS7 deposited during the early Pliocene and the Pleistocene.

- Our palaeogeographical reconstructions highlight uplifts and emergences of hundreds $\mathrm{km}$ - long islands during the late Eocene, the late Oligocene, the early Langhian, and the latest Miocene-earliest Pliocene. These uplift events have been interspersed by

\section{Acknowledgements}

This work was supported by the INSU TelluS-SYSTER grant call 2017, the GAARAnti project (ANR-17-CE31-0009), the GARANTI Cruise (2017) and the 
ANTITHESIS Cruise (2013). We are indebted to Saba Bank Resources N.V. for the provision

1009 of seismic lines of the Saba Bank area. We gratefully thank the captain and crew of $R / V$ 1010 L'Atalante, as well as the technical staff of Genavir for having successfully completed the acquisition of seismic data and dredge samples during the GARANTI and ANTITHESIS 1012 cruises (https://doi.org/10.17600/17001200). Multichannel seismic processing was performed 1013 with Geovation software of CGG and Seismic Unix. All geophysical data of the 1014 ANTITHESIS and GARANTI cruise are available on demand at SISMER 1015 (www.ifremer.fr/sismer/). Thin-sections were made by D. Delmas and C. Nevado 1016 (Montpellier) and F. Zami (Pointe à Pitre). Paul Mann, an anonymous reviewer and Editor 1017 Christopher Fieding are thanked for their constructive reviews. 

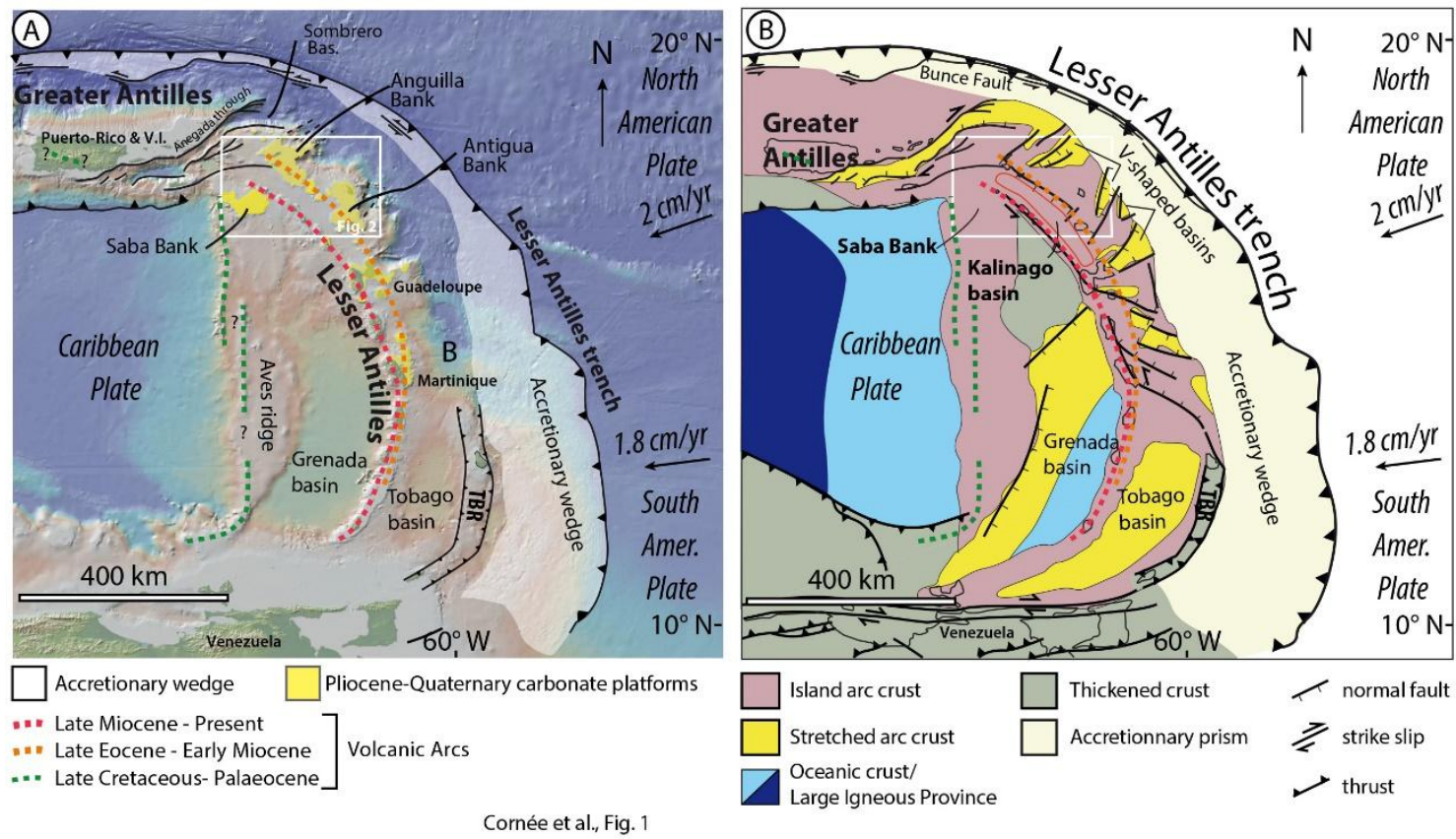

1029 Fig. 1: A: tectonic setting of the Lesser Antilles subduction zone; B: schematic map of the main crustal blocks; the main faults are drawn from Jany et al. (1990), Feuillet et al. (2002, 2010), Clark et al. (2008), Gomez et al. (2018), Garrocq et al. (2020), Padròn et al. (2020), and Boucard et al. (2021). The study area is delineated by the white rectangle. TBR: Tobago Barbados Ridge.

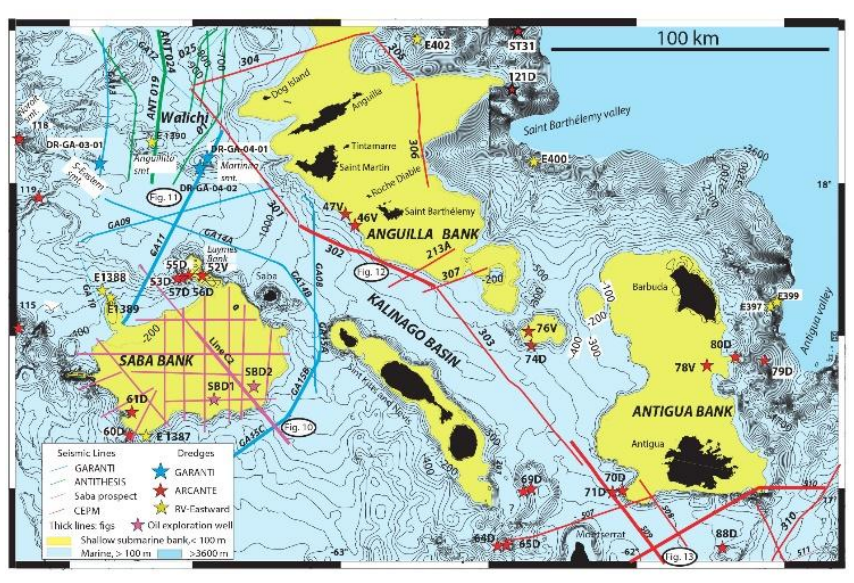

Fig. 2: Location of the studied seismic profiles, dredges and investigated islands of Anguilla and Antigua banks. Thick lines correspond to seismic lines of figures 10 to 13 . 


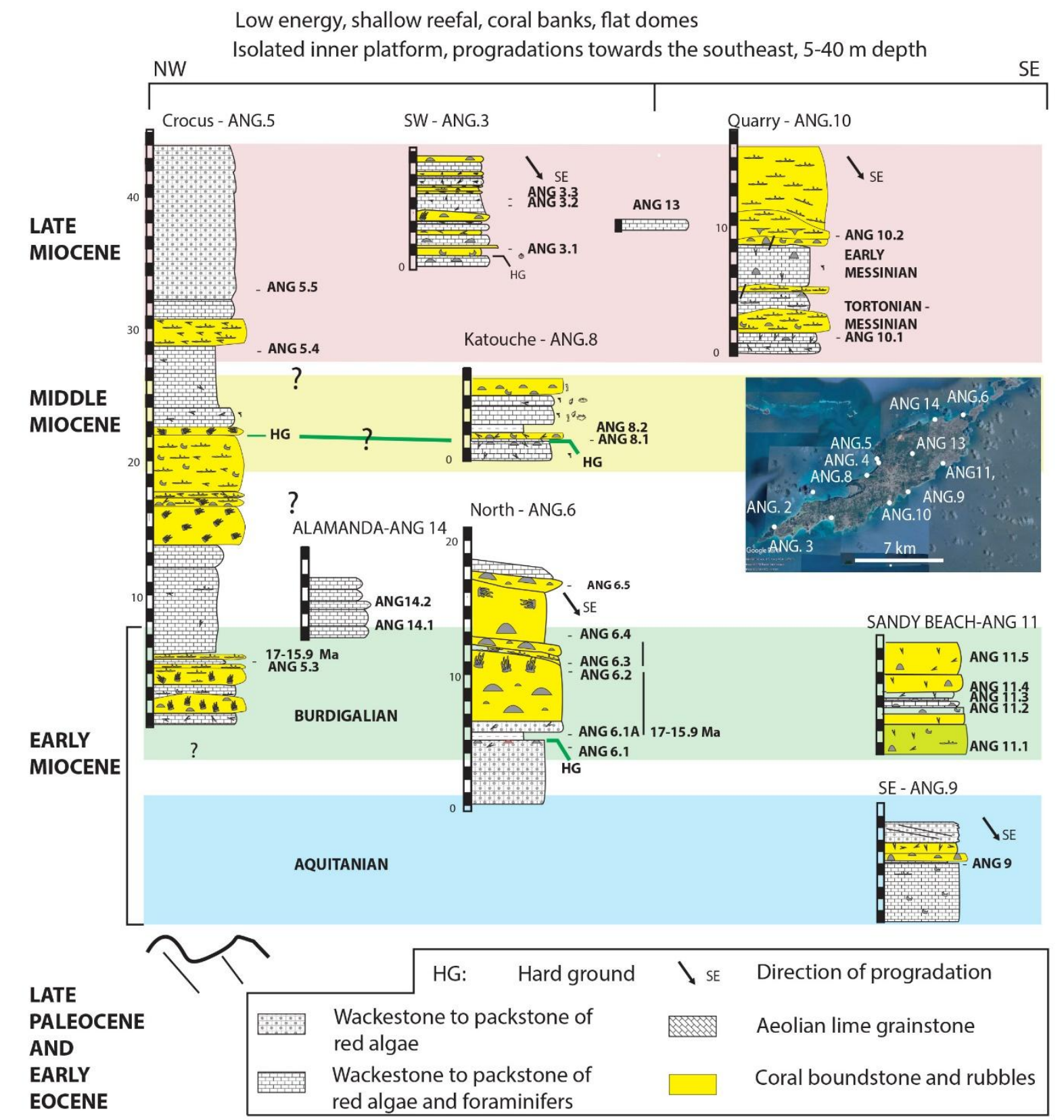

1040 Fig. 3: Correlations of the cross-sections in Anguilla. The location, description and 1041 depositional settings of the sections, as well as the palaeontological content of the collected 1042 samples are detailed in Appendix C. 


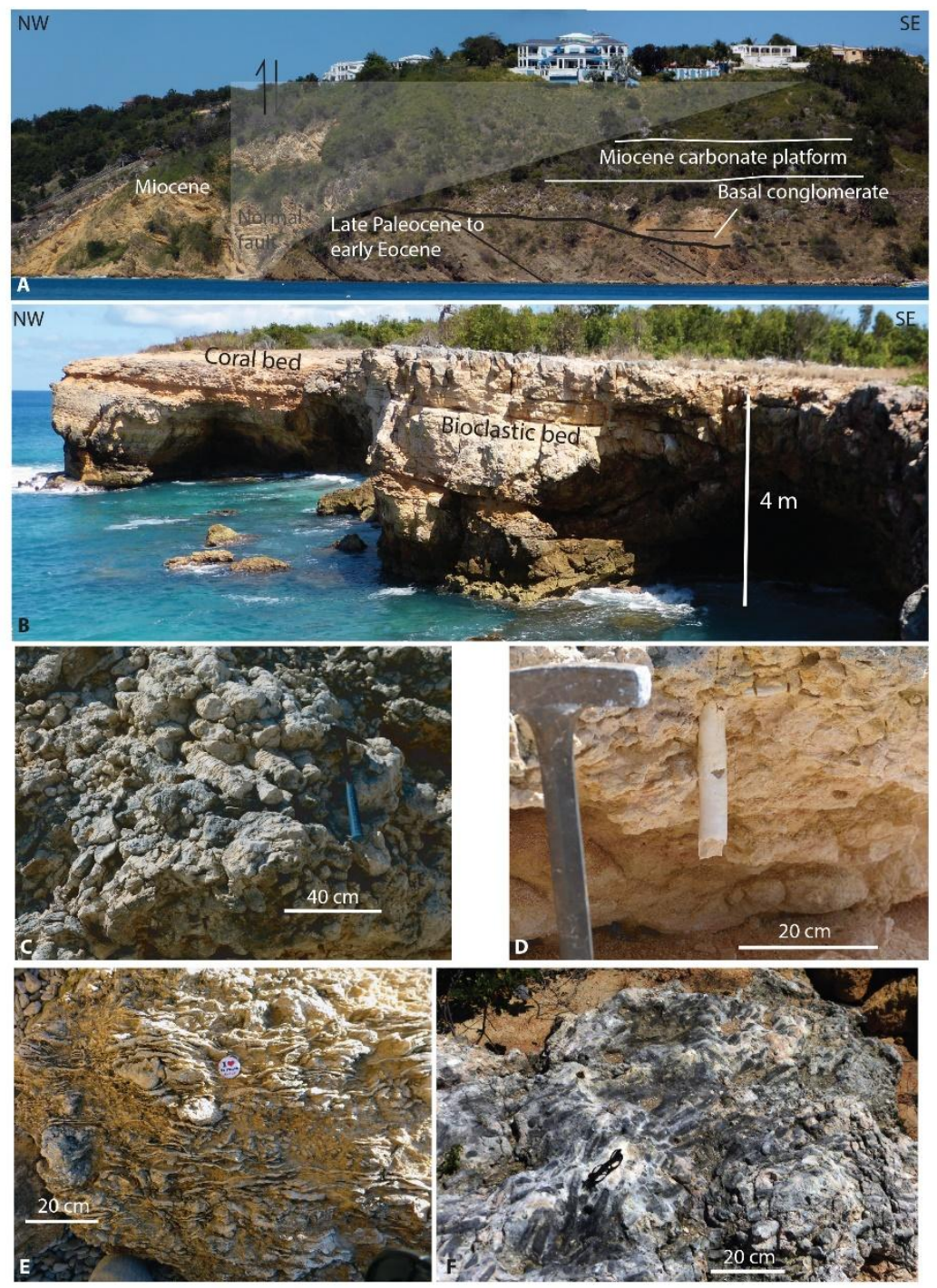

1046 Fig. 4: Field view of Anguilla. A: southeastward tilted upper Palaeocene to lower Eocene 1047 turbidites overlain by sub-horizontal, undated conglomerates then lower Miocene reefal 1048 carbonates (Crocus Bay); B: typical aspect of the coral and bioclastic banks (locality ANG 3, 1049 late Miocene; Appendix C); C: detail view of a coral biostromal bed with sub-horizontal thick 1050 branched Porites colonies (locality ANG 6, Burdigalian); D: Teredo in life position (locality 1051 ANG 3, late Miocene); E: sheet-like Porites coral colonies with some massive ones (locality 1052 ANG 10, late Miocene); F: m- high patch reef build-up with branching colonies of 1053 undertermined genus (locality ANG 3, late Miocene). 


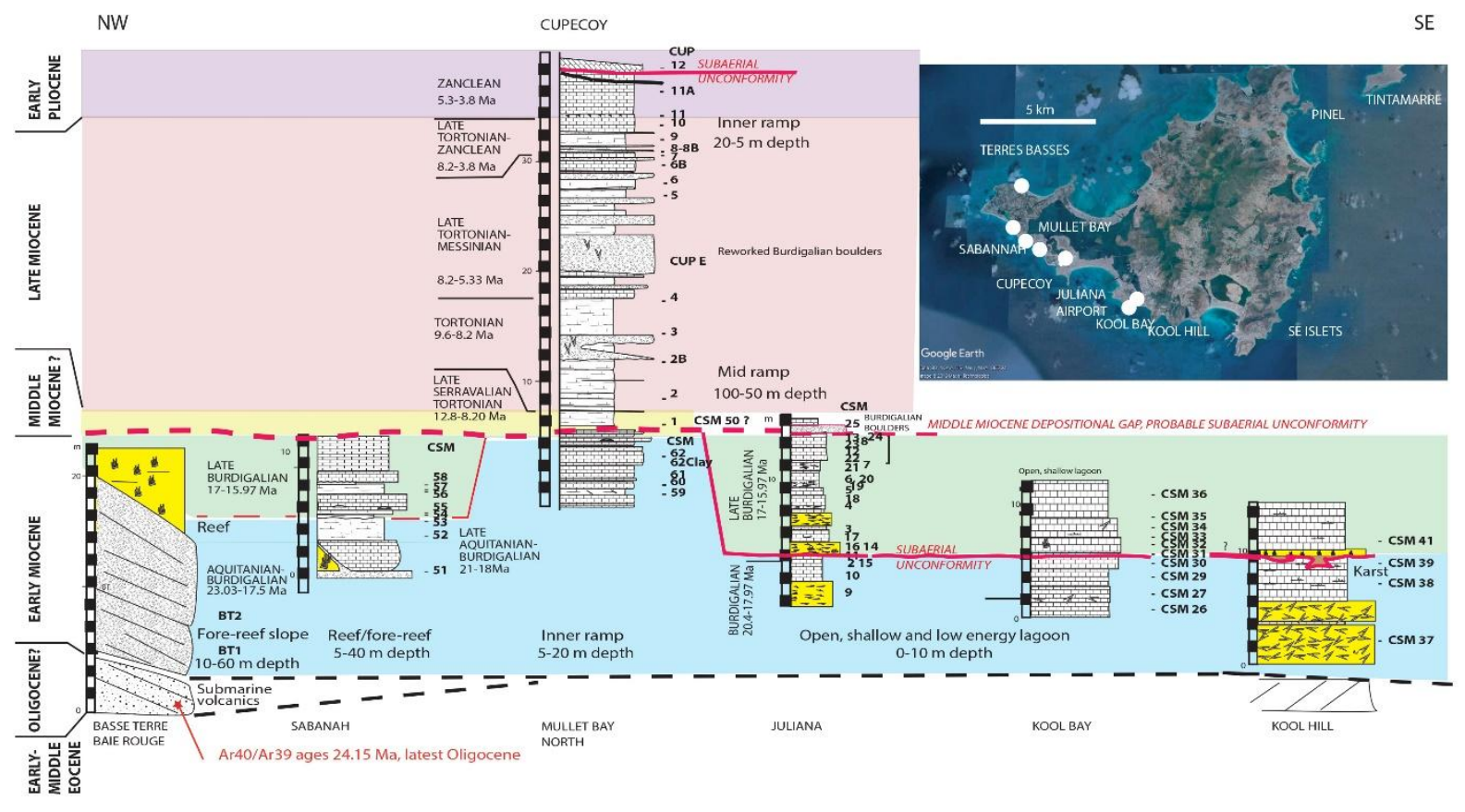

1056 Fig. 5: Correlations in St Martin. The location, description and depositional settings of the 1057 sections, as well as the palaeontological content of the collected samples, are detailed in 1058 Appendix D. 


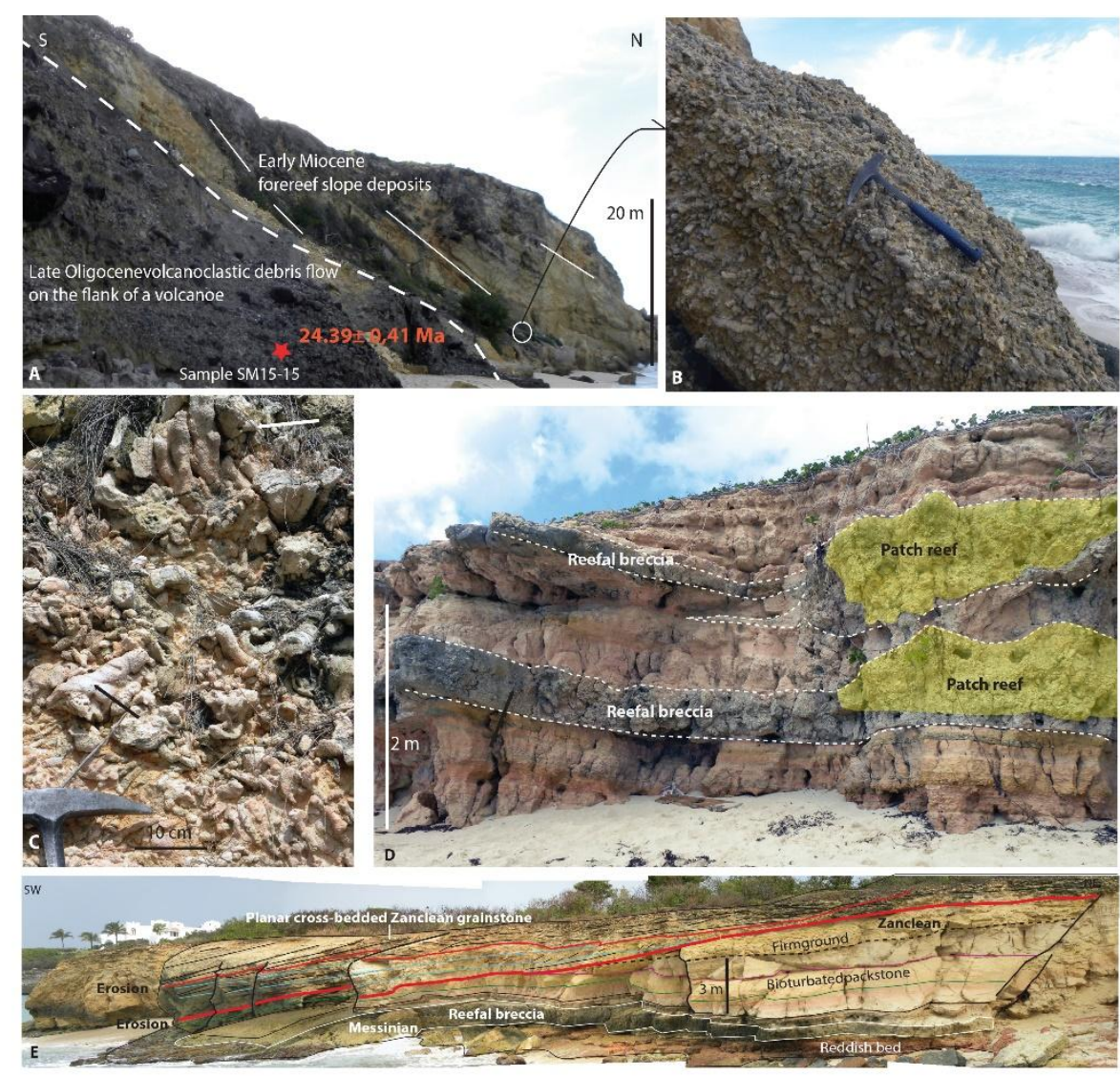

1062 Fig. 6: Field view of St Martin. A and B: lower Miocene reefal/forereef slope deposits 1063 composed of coral debris above Oligocene lahars (Terres Basses, Baie Rouge; location in 1064 Appendix D); C: lagoonal, Burdigalian biostromal coral beds (Juliana airport); D: inner ramp 1065 patch reefs and associated coral breccias, late Miocene (Cupecoy Bay); E: intra-Zanclean 1066 erosional surfaces (Cupecoy). 


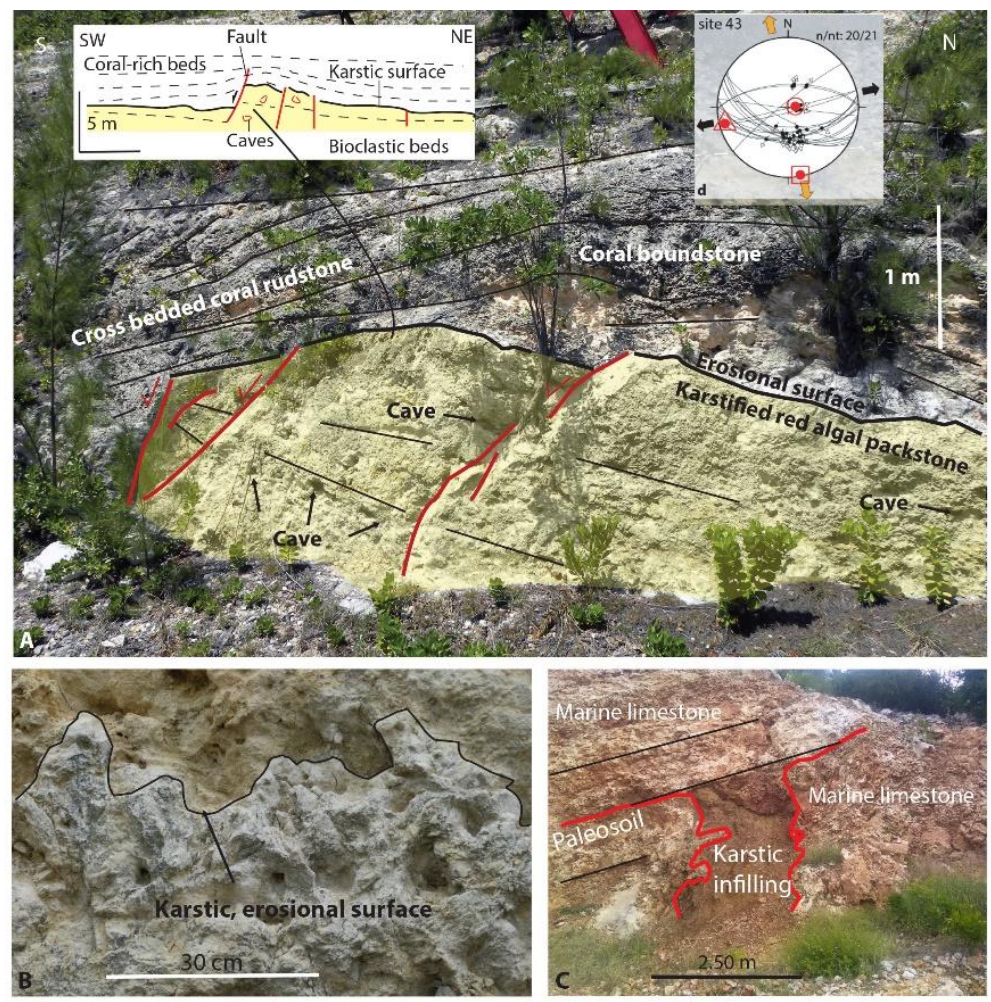

1069 Fig. 7: Emergence features in the upper Burdigalian deposits. A: synsedimentary normal 1070 faults in the Burdigalian lagoonal deposits (Juliana airport; stress tensors from Legendre, 1071 2018). The horst structure is topped by an emersion surface below which microcaves were 1072 found; B: detailed view of the emersion surface with karstic gullies sealed by the overlying 1073 deposits; C: palaeosoil and karstic cave infilled with red silty clay within Burdigalian reefal 1074 beds; the cave is sealed by Burdigalian marine bioclastic limestones (southern side of Kool 1075 Hill). 
E

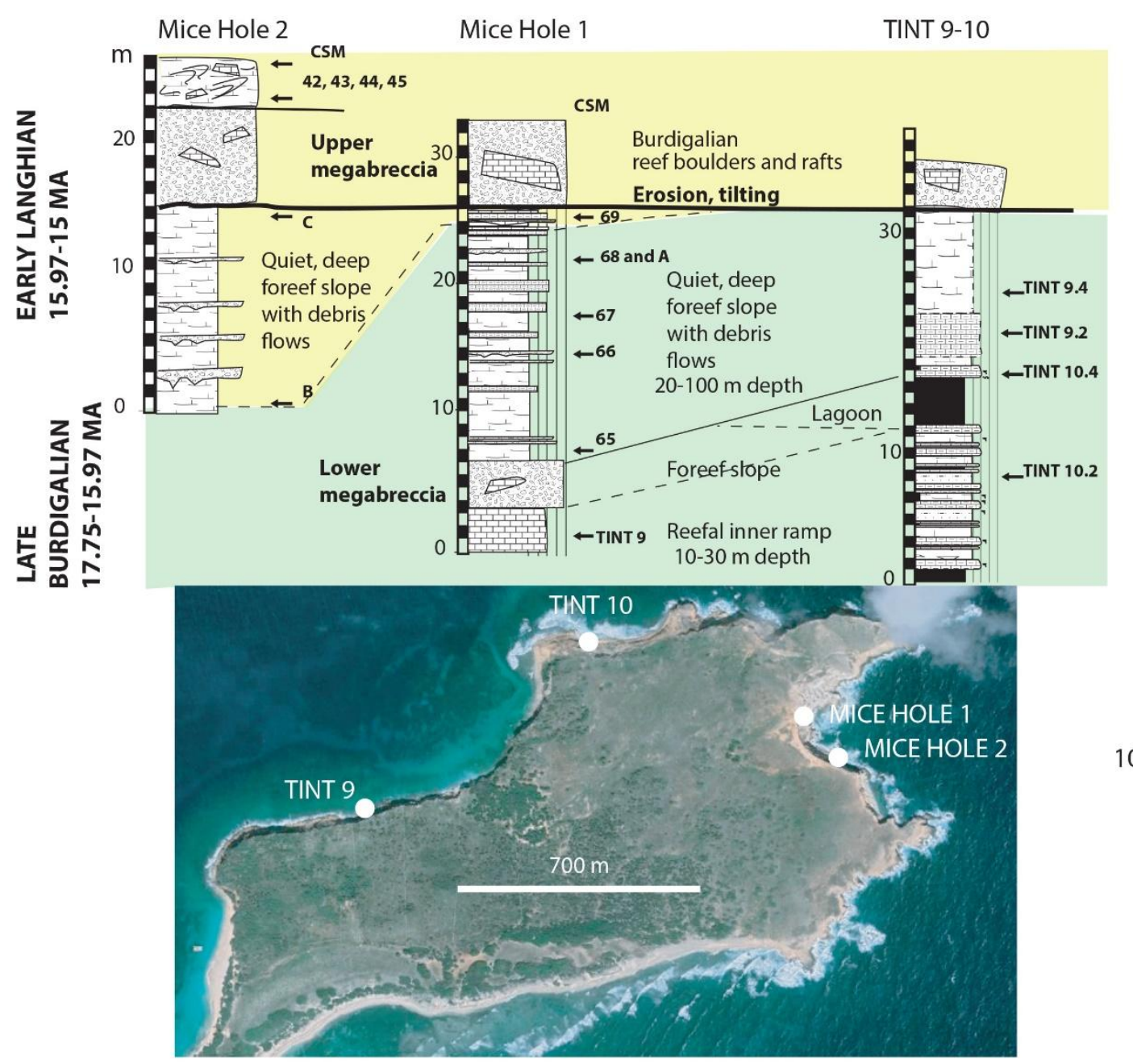

1078 Fig. 8: Correlations in Tintamarre. The location, description and depositional settings of the 1079 sections, as well as the palaeontological content of the collected samples are detailed in 1080 Appendix E. 

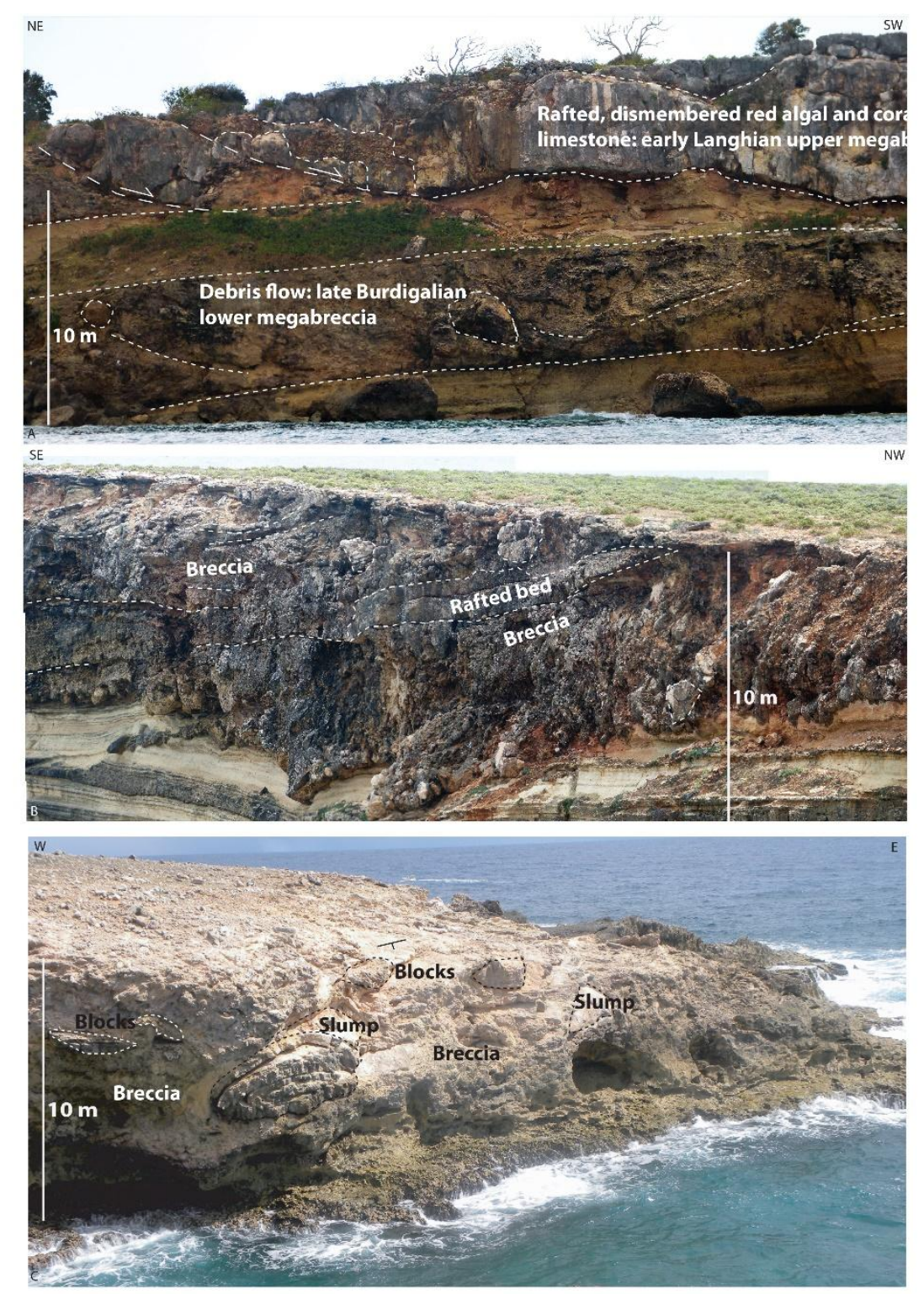

1084 Fig. 9: Megabreccias at Tintamarre, locations in Appendix E. A: lower and upper 1085 megabreccias with early Miocene (20-16 Ma) rafted blocks into bioclastic forereef slope 1086 (northern cliff of Tintamarre, 200m west from locality TINT 10). In this area, most of the 1087 upper Burdigalian and lower Langhian deposits have been removed below the upper 1088 megabreccia; B: detailed view of the middle Miocene (15.4-15 Ma) upper megabreccia 1089 consisting of Burdigalian rafted limestone beds and dm- to m- wide blocks (Mice Hole 2 1090 locality); C: pink, uppermost part of the middle Miocene (15.4-15 Ma) upper megabreccia 1091 with m-sized block and large isoclinal fold slumps (locality CSM 43). 


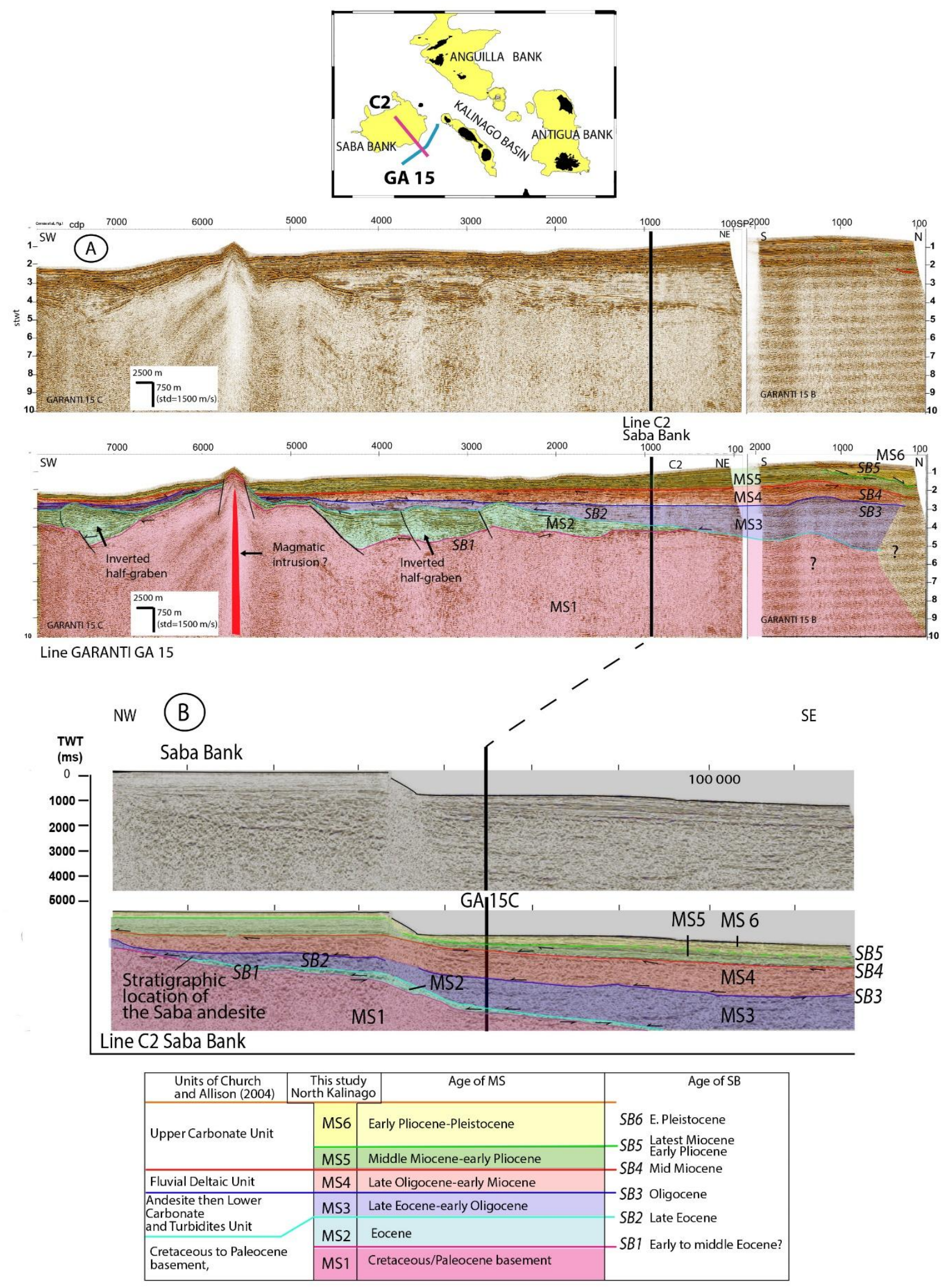

Cornée et al. Fig.10

Fig. 10: Reference seismic lines. A: GARANTI GA15 line; B: C2 line (Matchette-Downes,

1094 2007, re-interpreted). MS: megasequence; SB: sequence boundary. 

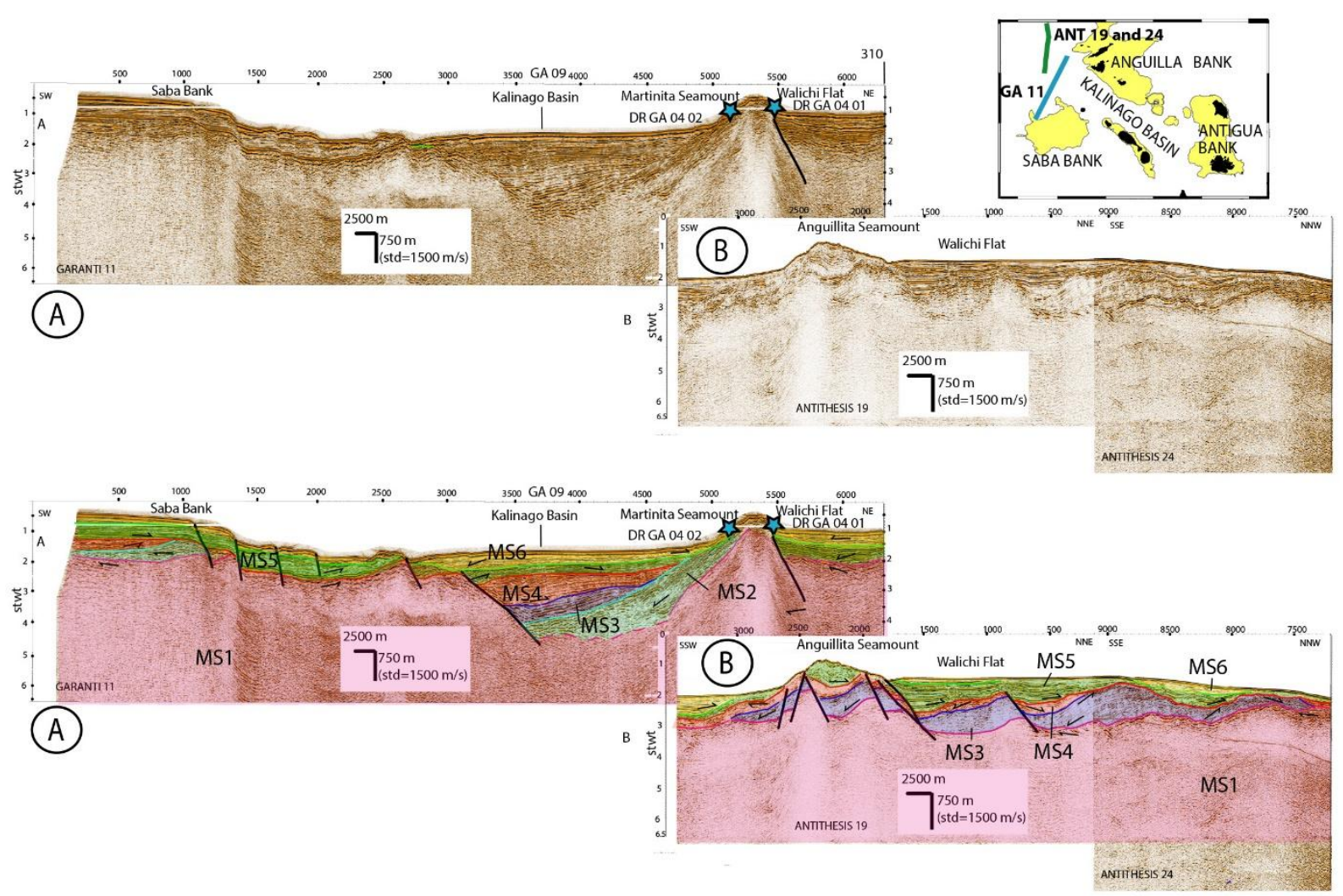

1097 Fig.11: A: GARANTI seismic line GA11; B: ANTITHESIS seismic lines 19 and 24. The 1098 Kalinago Rift opened during deposition of MS3 and MS4, which were deposited into syn1099 sedimentary half-grabens. MS2 is only preserved in the vicinity of the Martinita Seamont. 1100 Some syn-sedimentary faults were active during deposition of MS3 and M4 only. A part of 1101 these fault was reactivated later during deposition of MS5 (Anguillita Spur) and others are 1102 recent (Saba bank). 


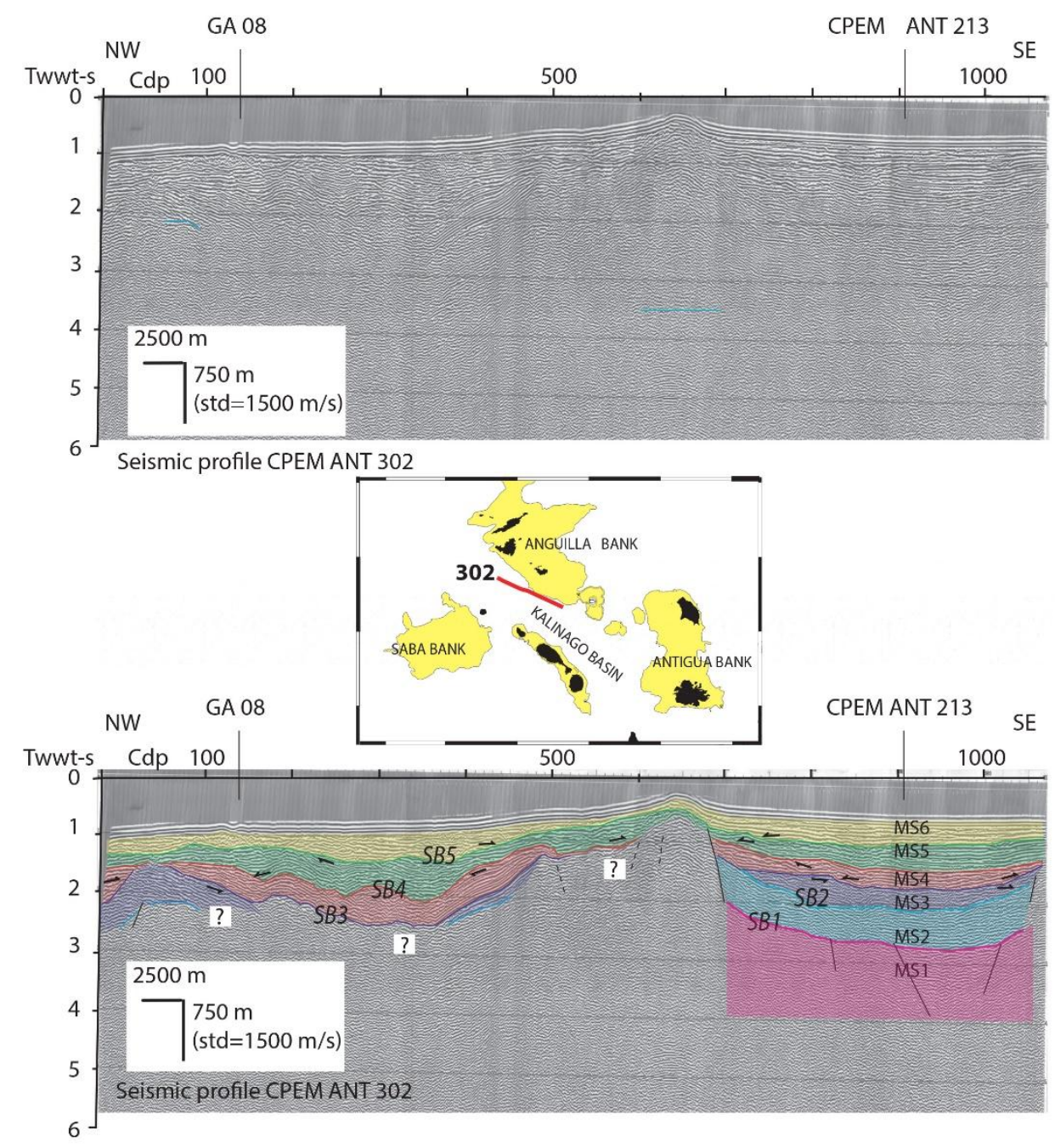

Cornée et al. Fig. 12

1105 Fig. 12: CPEM seismic line 302. Sequence boundaries display an erosional character. MS2 is 1106 preserved as a relict patch only to the SE of the seismic profile below SB2. The Kalinago Rift 1107 opened from MS3 to MS6. 

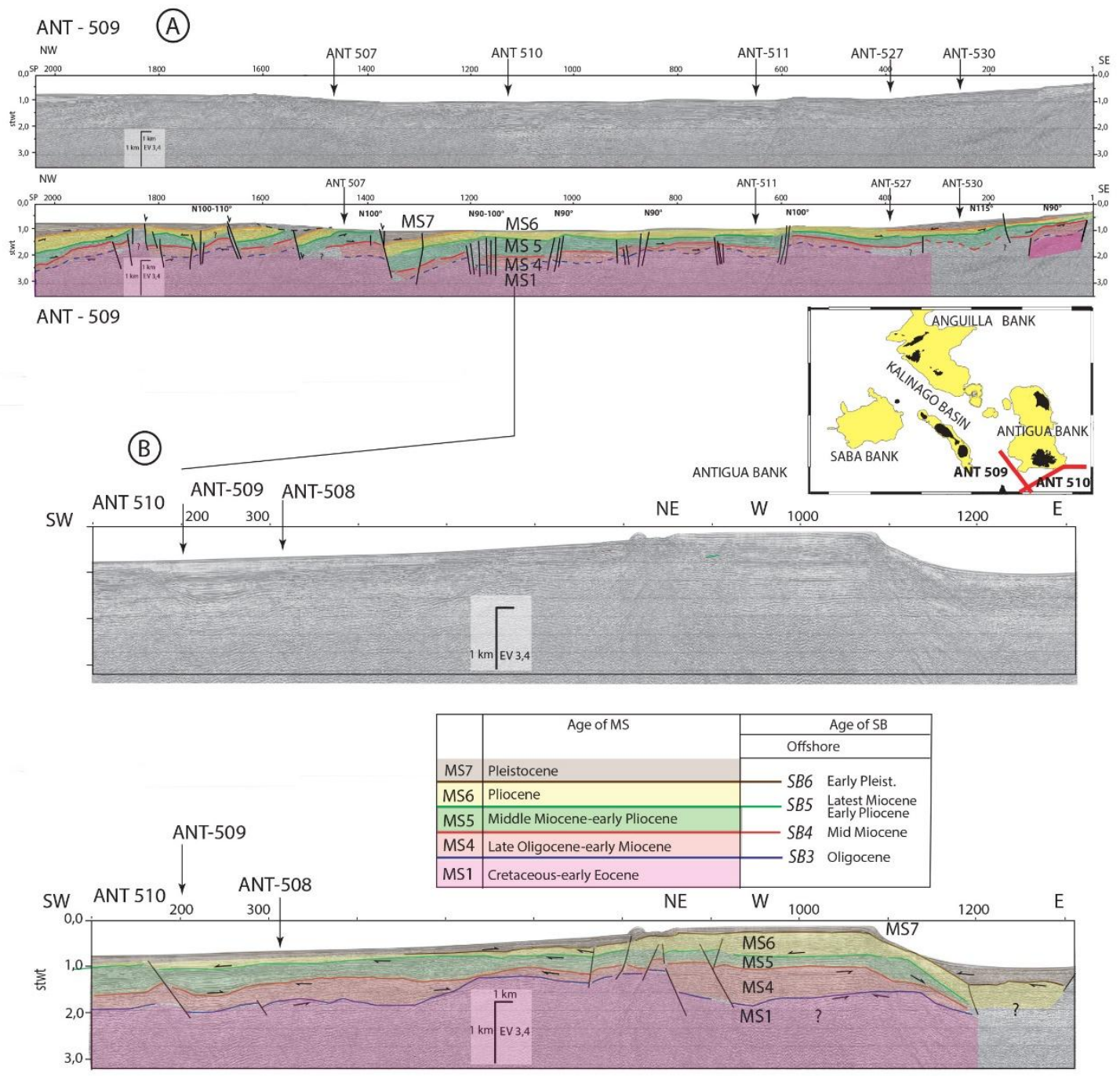

1110 Fig. 13: A: CPEM line 509; B: CPEM line 510. In the southern part of the Kalinago Basin,

1111 MS2 and MS3 are missing. MS7 can be separated from MS6. The basin opened during

1112 deposition of MS4 (late Oligocene), later than its northern part (MS3, early Oligocene). 
SSW

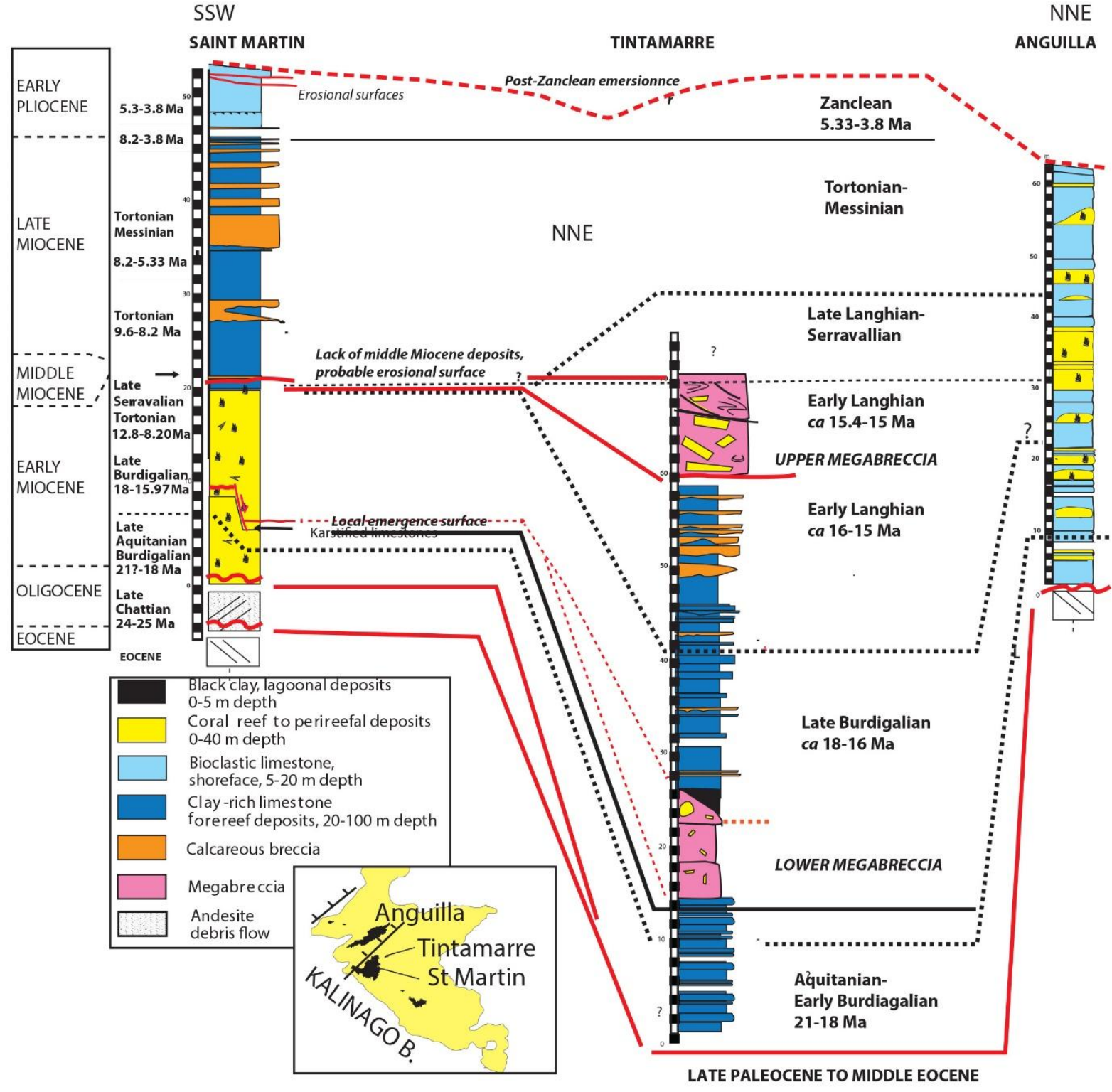

1114 Fig. 14: Synthetic Cenozoic lithostratigraphies and correlations of St Martin, Tintamarre and 1115 Anguilla islands. 


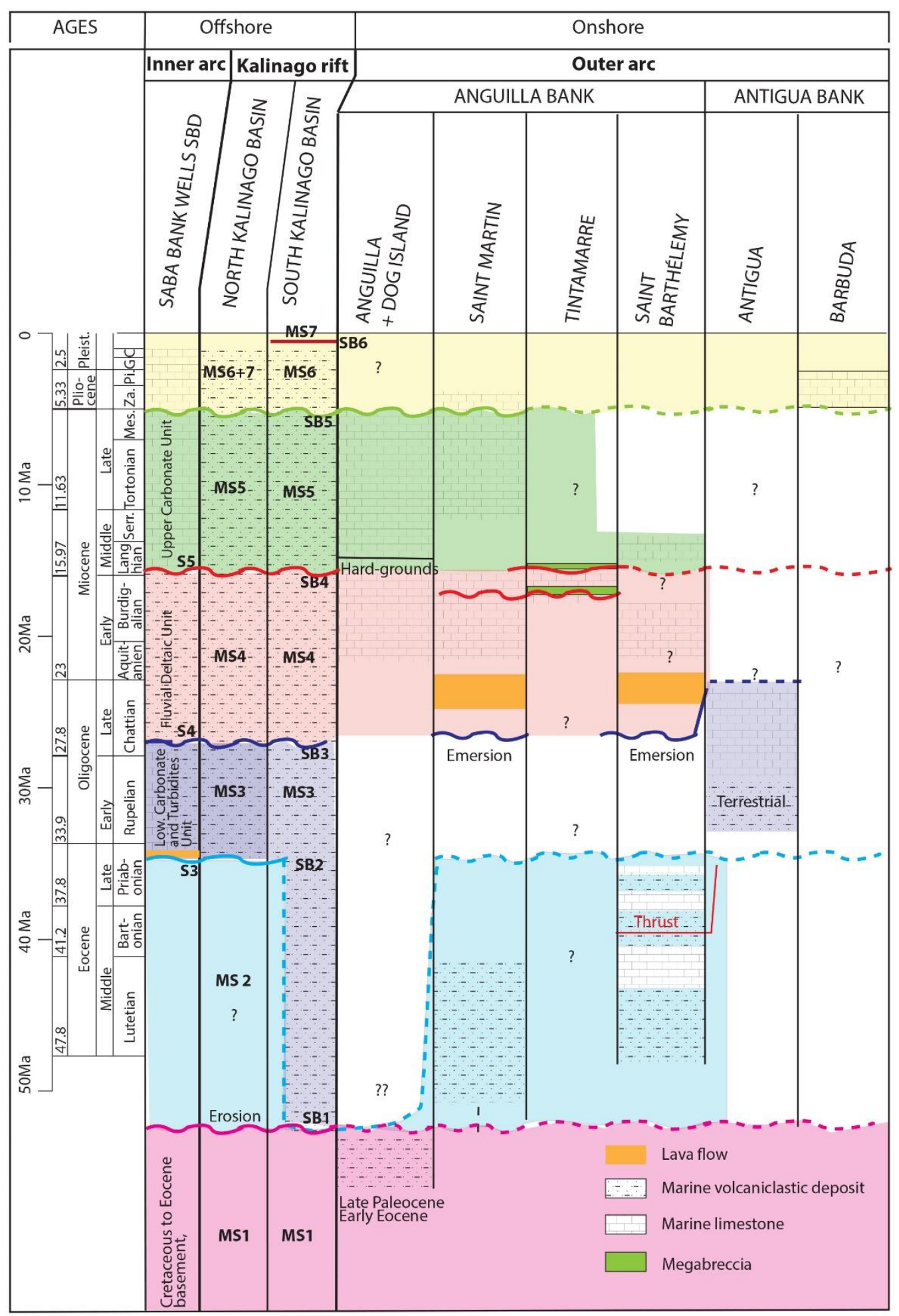

Cornée et al., Fig. 15

1119 15: Onshore-offshore correlations in the northern Lesser Antilles. Onshore, SB2 and SB3 are often stacked in a single erosional surfac 


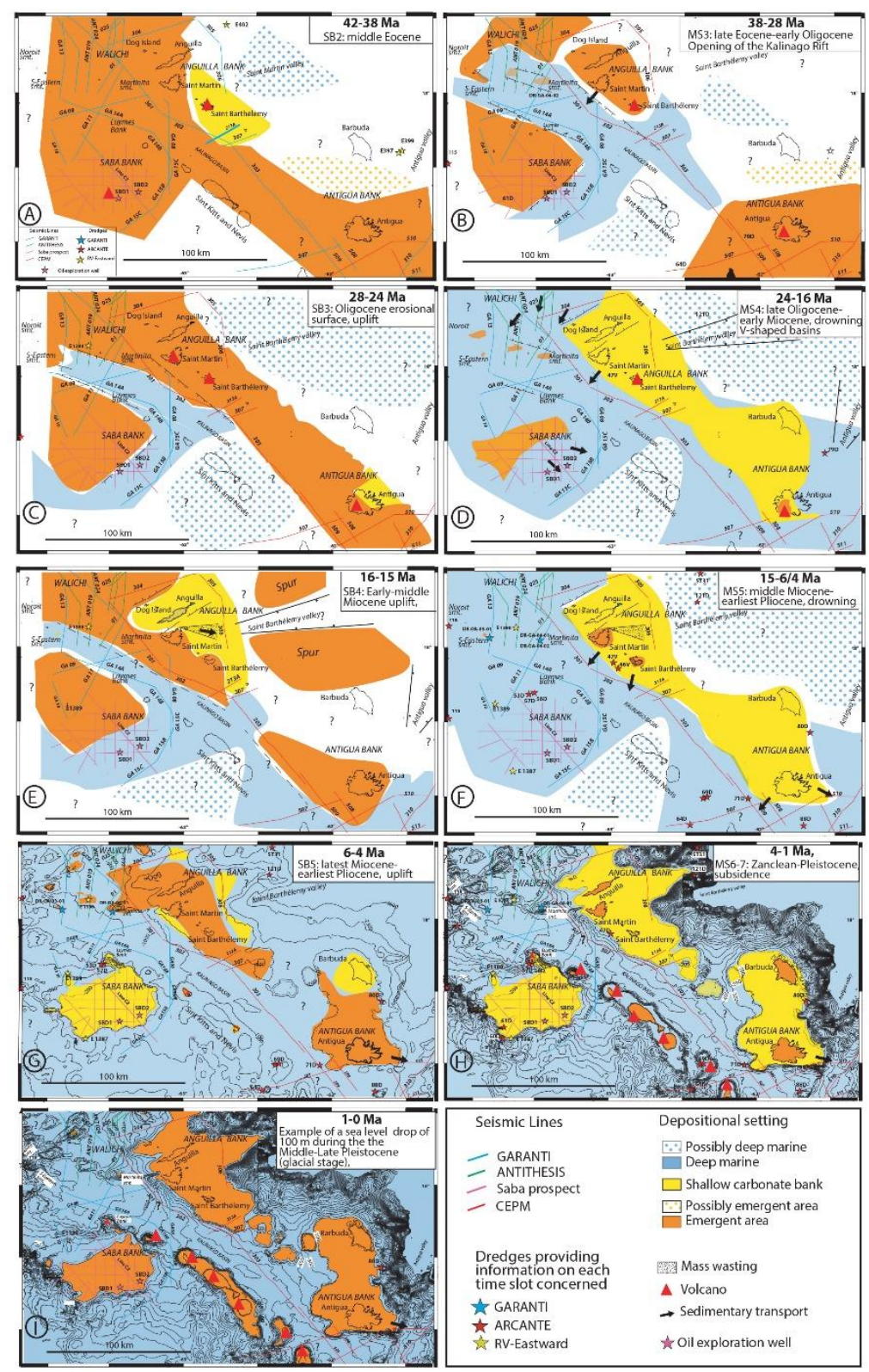

Fig. 16: Paleogeographic maps of the northern Lesser Antilles, reconstructed from the late Eocene to the Middle-Late Pleistocene. A: end of late Eocene compression; B: opening of the Kalinago Basin; C: propagation of the Kalinago Basin; D: late Oligocene-early Miocene drowning; E: opening of the V-shaped basins and uplift (Boucard et al., 2021); F: middle Miocene-earliest Pliocene drowning; G: latest Miocene-earliest Pliocene uplift; H: Zanclean-Calabrian drowning; I: example of emerged areas during middle-late Pleistocene glacial maxima (considering $100 \mathrm{~m}$ sea level drops). Supplementary data 
1131 Appendix A: Microphotographs of stratigraphically significant calcareous nannofossil taxa 1132 from the samples collected in the northern Lesser Antilles.Appendix B: Microphotographs of 1133 stratigraphically significant foraminiferal taxa from the samples collected in the northern 1134 Lesser Antilles.

Appendix C: Lithostratigraphical successions of Anguilla with depositional settings and microfossil content.

Appendix D: Lithostratigraphical successions of St Martin with depositional settings and microfossil content.

Appendix E: Lithostratigraphical successions of Tintamarre with depositional settings and microfossil content.

Appendix F: Lithostratigraphical succession of the Highland Fm. of Barbuda with depositional settings and microfossil content.

Appendix G: Lithostratigraphical successions of St Barthélemy and Antigua with depositional settings and microfossil content.

Appendix H: Dredged samples in the northern Lesser Antilles; locations Fig. 2. microfossil contents. 
Appendix J: Seismic lines CPEM 213 (Bouysse et al., 1994, re-interpreted) and GARANTI

GA08 and 09.

Appendix K: Radiometric dating of a lava in St Martin, Terres Basses.

\section{References}

Ali JR., 2012 Colonizing the Caribbean: is the GAARLandia land-bridge hypothesis gaining a

Andréieff P., Bouysse P. and Westercamp D., 1980. Reconnaissance géologique de l'arc insulaire des Petites Antilles. Résultats d'une campagne à la mer de prélèvementsde roches entre Sainte Lucie et Anguilla. Rapport Bur. Géol. Min., Orléans (F), 80 SGN 086 MAR, 70 pp.

Andréïeff P., Bouysse P. and Westercamp D., 1987. Géologie de l'arc insulaire des Petites Antilles, et évolution géodynamique de l'EStCaraïbe, Thèse de Doctorat d'état, Université de Bordeaux I.

Andréïeff P.,, Baubron J.C. and Westercamp D., 1988a. Histoire géologique de la Martinique (Petites Antilles): biostratigraphie (foraminifères), radiochronologie (potassium-argon), évolution volcano-structurale. Géol. Fr., 2-3, 39-70.

Andréïeff P., Westercamp D., Garrabé F. and Bonneton J.R., 1988b. Stratigraphie de l'île de Saint-Martin. Géol. Fr., 2-3, 71-88.

Boschman L. M., van Hinsbergen D. J. J., Torsvik T. H., Spakman, W. andPindell, J. L., 2014. Kinematic reconstruction of the Caribbean region since the Early Jurassic. Earth-Sci. Rev., 138, 102-136.

Boucard M., Lebrun J.-F., Marcaillou B., Laurencin M., Klingelhoefer, F., Laigle, M., Lallemand, S., Schenini L., Graindorge D., Cornée J.-J., Münch, P., Philippon M., and the ANTITHESIS 1, 3 Teams, 2021 (in press). Paleogene V-shaped basins and Neogene subsidence of the Northern Lesser Antilles forearc. Tectonics. https://doi.org/10.1029/2020TC006524

Boudagher-Fadel M. K., 2008. Evolution and significance of larger benthic foraminifera. In : Developments in Paleontology and stratigraphy 21 (ed. P. B. Wignall), 540 pp., Amsterdam, Elsevier.

Boudagher-Fadel M. K., 2015. Biostratigraphic and Geological Significance of Planktonic Foraminifera (Updated 2nd Edition). London, UCL Press, 298 pp. doi:10.14324/111.9781910634257 
Boudagher-Fadel M.K., 2018. Revised Diagnostic First and Last Occurrences of Mesozoic and Cenozoic Planktonic Foraminifera. UCL Office of the Vice-Provost Research,

\section{Professional Papers Series, 2, 1-5. http://www.es.ucl.ac.uk/people/fadel/home-mkf.htm}

Bouysse P. and Guennoc P., 1983. Données sur la structure de l'arc insulaire desPetites Antilles entre St Lucie et Anguilla. Mar. Geol. 53, 131- 166.

Bouysse P. and Mascle A., 1994. Sedimentary Basins and Petroleum Plays Around the French Antilles. In: Mascle A. (eds) Hydrocarbon and Petroleum Geology of France. Special Publication of the European Association of Petroleum Geoscientists, 4. Springer. https://doi.org/10.1007/978-3-642-78849-9 3

Bouysse P., Andréïeff P., Richard M., Baudron J.C., Mascle A., Maury R. and Westercamp, D., 1985a. Aves swell and northern Lesser Antilles Ridge: Rock-dredging results from ARCANTE 3 cruise. In: A. Mascle (Ed.), Caribbean geodynamics, Technip, Paris 65-76.

Bouysse P., Baudron J.C., Richard M., Maury R. and Andréïeff P., 1985b. Evolution de la terminaison nord de l'arc interne des Petites Antilles au Plio-Quaternaire. Bull.Soc.géol. Fr., I, 181-188. https://doi.org/10.2113/gssgfbull.I.2.181

Brace S., Turvey S. T., Weksler M., Hoogland M. L. P. and Barnes I., 2015. Unexpected evolutionary diversity in a recently extinct Caribbean mammal radiation. Proc. Roy.Soc. London, B, 282, 20142371.

Brasier M. D. and Mather J.D.,1975. The stratigraphy of Barbuda, West Indies. Geol. Mag., $112,271-282$.

Brasier M.D. and Donahue J., 1985. Barbuda-An emerging reef and lagoon complex on the edge of the Lesser Antilles island arc. J. geol. Soc. London, 142, 1101-1117.

Briden J. C., Rex D. C., Faller A. M. and Tomblin J. F., 1979. K-Ar geochronology and palaeomagnetism of volcanic rocks in the Lesser Antilles island arc. Philo. Trans. Royal Soc. A: Mathematical, Physical and Engineering Sciences, 291, 485-528. doi.org/10.1098/rsta.1979.0040

Budd A.F., Johson K.G. and Edwards J.C., 2005. Caribbean reef coral diversity during the early to middle Miocene: an example from the Anguilla Formation. Coral reefs, 14, 109-117.

Calais E., Symithe S., de Lépinay B. M. and Prépetit C., 2016. Plate boundary segmentation in the northeastern Caribbean from geodetic measurements and Neogene geological observations. C. R. Geoscience, 348, 42-51.

Carey S., Sparks R. S. J., Tucker M. E., Li T., Robinson L., Watt S. F. L., ... and Ballard R. D., 2020. The polygenetic Kahouanne Seamounts in the northern Lesser Antilles island arc: evidence for large-scale volcanic island subsidence. Marine Geology, 419, https://doi.org/10.1016/j.margeo.2019.106046).

Cattuneanu O., 2006. Principles of sequence stratigraphy. Elsevier, 369 pp. 
Chaytor J. D. and ten Brink U. S., 2015. Event sedimentation in low-latitude deep-water carbonate basins, Anegada Passage, northeast Caribbean. Basin Res., 27, 310-335. doi:10.1111/bre.12076.

Christman R. A., 1953. Geology of St Bartholomew, St Martin, and Anguilla, Lesser Antilles. Geol. Soc. Ameri., Bull., 64, 65-96. https://doi.org/10.1130/00167606(1953)64\%5B85:GOSBSM\%5D2.0.CO;2

Church R. E. and Allison K. R., 2004. The Petroleum Potential of the Saba Bank Area, Netherlands Antilles. Search and Discovery Article \# 10076. Posted December 20, 2004

Clarck, S.A., Sobiesiak, M., Zelt, C.A., Magnani, M.B., Miller, M.S., Bezada, M.J., Levander, A., 2008. Identification and tectonic implications of a tear in the South American plate at the southern end of the Lesser Antilles. Geochemistry, Geophysics, Geosystems, 9, Q11004. doi:10.1029/2008GC002084.

Cornée J.-J., Léticée J.-L., Münch P., Quillévéré F., Lebrun J.-F., Moissette P., Braga J.C., Melinte- Dobrinescu M., De Min L., Oudet J., Randrianasolo A., 2012. Sedimentology, paleoenvironments and biostratigraphy of the Pliocene- Pleistocene carbonate platform of Grande- Terre (Guadeloupe, lesser Antilles fore-arc). Sedimentology, 59, 1426- 1451.

Cornée J.- J., BouDagher- Fadel M., Philippon M., Léticée J.- L., Legendre L., Maincent G., Lebrun J.- F., and Münch P., 2020 Paleogene carbonate systems of Saint Barthélemy, Lesser Antilles: stratigraphy and general organisation. Newsl. Stratigr. doi:10.1127/nos/2020/0587.

Courcelle M., Tilak M.-K., Leite Y. L. R., Douzery E. J. P. and Fabre, P.-H., 2019. Digging for the spiny rat and hutia phylogeny using a gene capture approach, with the description of a new mammal subfamily. Mol. Phylog. Evol., 136, 241-253.

Coussens M.F. et al., 2012. Synthesis: stratigraphy and age control for IODP Sites U1394, U1395, and U1396 offshore Montserrat in the Lesser Antilles. In: Le Friant, A., Ishizuka, O., Stroncik, N.A., and the Expedition 340 Scientists. Proc. IODP 340. doi:10.2204/iodp.proc.340.204.2016.

Dagain J., Andréieff P., Westercamp D., Bouysse P. and Garrabé F., 1989. Carte géologique de France (1:50000), feuille Saint Martin. Bureau de Recherches Géologiques et Minières, Orléans (Fr).

Dávalos L. M., 2004. Phylogeny and biogeography of Caribbean mammals. Biol. J. Linnean Soc., 81, 373-394.

Dailey S.K., Clift P.D., Kulhanek D.K et al., 2019. Large-scale mass wasting on the Miocene continental margin of western India. Geol. Soc. Amer. Bull., 132, 85-112. doi.org/10.1130/B35158.1

Daly T.E. (1995) The Petroleum Potential of the Netherlands Antilles. In: Miller R.L., Escalante G., Reinemund J.A., Bergin M.J. (eds), Energy and Mineral Potential of the Central American-Caribbean Region. Circum-Pacific Council for Energy and Mineral Resources Earth Science Series, 16, Springer. https://doi.org/10.1007/978-3-642-79476-6 14 
Defand M.J., Sherman S., Maury R.C., Bellon H. de Boer J., Davidson J. and Kepezhinskas P., 2001. The geology, petrology, and petrogenesis of Saba Island, Lesser Antilles. J. Volc. Geoth. Res., 107, 87-111.

Delsuc F., Kuch M., Gibb G. C., Karpinski E., Hackenberger D., Szpak P., Martinez J. G., Mead J. I., McDonald H. G., MacPhee R. D. E. Billet, G., Hautier L. and Poinar H. N., 2019. Ancient mitogenomes reveal the evolutionary history and biogeography of sloths. Current Biology, 29, 1-12.

De Min L., 2014. Sismo-stratigraphie multi-échelle d'un bassin avant-arc: Architecture du bassin de Marie-Galante, Petites Antilles. Sciences de la Terre. PhD Thesis, Université des Antilles et de la Guyane (UAG), Pointe à Pitre, Guadeloupe, F. https://hal.archivesouvertes.fr/tel-03144281

De Min L., Lebrun J. F., Cornée J. J., Münch P., Léticée J. L., Quillévéré, F., et al., 2015. Tectonic and sedimentary architecture of the Karukéra spur: A record of the Lesser Antilles fore-arc deformations since the Neogene. Marine Geology, 363, 15-37. https://doi.org/10.1016/j.margeo.2015.02.007

Donovan S. K., Jackson T. A., Harper D. A., Portell, R. W. and Renema W., 2014. The upper Oligocene of Antigua: the volcanic to limestone transition in a limestone Caribbee. Geology Today, 30, 151-158.

Fabre P.-H., Vilstrup J. T., Raghavan M., Der Sarkissian C., Willerslev E., Douzery E. J. P. and Orlando, L.,2014. Rodents of the Caribbean: origin and diversification of hutias unravelled by next-generation museomics. Biol. Lett., 10, 20140266.

Favier A., Lardeaux J.-M., Legendre L., Verati C., Philippon M., Corsini M., Münch P. and Ventalon S., 2019. Tectono-metamorphic evolution of shallow crustal levels within active volcanic arcs. Insights from the exhumed Basal Complex of Basse-Terre (Guadeloupe, French West Indies). BSGF - Earth Sci. Bull., 190,10. https://doi.org/10.1051/bsgf/2019011

Feuillet, N., Manighetti, I., Tapponnier, P., Jacques, E., 2002. Arc parallel extension and localization of volcanic complexes in Guadeloupe, Lesser Antilles. J. Geophys. Res.: Solid Earth, 107 ETG 3-1-ETG 3-29.

Feuillet N., Leclerc F., Tapponnier P., Beauducel F., Boudon G., Le Friant A., Deplus C., Lebrun J.-F., Nercessian A., Saurel J.-M. and Clément V., 2010. Active faulting induced by slip partitioning in Montserrat and link with volcanic activity: New insights from the 2009 GWADASEIS marine cruise data. Geoph. Res. Letters, 37, L00E15. doi:10.1029/2010GL042556,

Feuillet N., Beauducel F. and Tapponnier P., 2011. Tectonic context of moderate to large historical earthquakes in the Lesser Antilles and mechanical coupling with volcanoes. $J$. Geophys. Res.: Solid Earth 116(B10).

Fox P. J., Schreiber E. and Heezen B. C., 1971. The geology of the Caribbean crust: Tertiary sediments, granitic and basic rocks from the Aves Ridge. Tectonophysics, 12, 89-109. 
Frost S.H. and Weiss M.P., 1979. Patch reef communities and succession in the Oligocene of Antigua, West Indies. Geol. Soc. Amer. Bull., 90, 1094-1141.

Garrocq C., Lallemand S., Marcaillou B., Lebrun J.-F., Padron C., Klingelhoefer F., Laigle M., Munch P., Gay A., Shenini L., Beslier M.-O., Cornée J.-J., Mercier De Lepinay B., Quillevere F. and Boudagher-Fadel M., 2020. Genetic relations between the Aves Ridge and the Grenada back-arc basin, East Caribbean Sea. J. Geophys. Res. Solid Earth, 126, e2020JB020466. https://doi.org/10.1029/2020JB020466

Gomez S., Bird D. and Mann P., 2018. Deep crustal structure and tectonic origin of the Tobago-Barbados ridge. Interpretation, 6 (2): T471-T484. https://doi.org/10.1190/INT-2016$\underline{0176.1}$

Gradstein F. M., Ogg J. G., Schmitz M. D., Ogg G. M., 2012. The Geologic Time Scale 2012. Elsevier, 1- 144.

Hastie A.R., Cox S. and Kerr A.C., 2021. Northeast- or southwest-dipping subduction in the Cretaceous Caribbean gateway? Lithos. https://doi.org/10.1016/i.lithos.2021.105998

Hedges S. B., 1996. Historical biogeography of West Indian vertebrates. Ann. Rev. Ecol. System., 27, 163-196.

Hedges S.B., 2001. Caribbean biogeography: an outline. In: Biogeography of the West Indies: patterns and perspectives (eds CA Woods, FE Sergile), CRC Press, Boca Raton, FL ,15-33.

Hedges S.B., 2006. Palaeogeography of the Antilles and origin of the West Indian terrestrial vertebrates. Annals of the Missouri Botanical Garden, 93, 231-244.

Hedges S.B., Hass C.A., Maxson L.R., 1992. Caribbean biogeography: molecular evidence for dispersal in West Indian terrestrial vertebrates. Proc. Natl Acad. Sci. USA, 89, 1909-1913. doi:10.1073/pnas.89.5.1909

Hine A.C., Locker S.D., Tedesco L.P., Mullins H.T., Hallock P., BelknapD.F., Gonzales J.L., Neuman A.C. and Snyder S.W, 1992. Megabreccia shedding from modern, low-relief carbonate platforms, Nicaraguan Rise. Geol. Soc. Amer. Bull., 104, 928-943.

Iturralde-Vinent M. A.,2006. Meso-Cenozoic Caribbean palaeogeography: implications for the historical biogeography of the region. Int. Geol. Rev., 48, 791-827.

Iturralde- Vinent M.A. and MacPhee R.D.E., 1999 Palaeogeography of the Caribbean region: implications for Cenozoic biogeography. Bull. Am. Mus. Nat. Hist, 238, 1-95.

Jany I., 1989. Néotectonique au sud des Grandes Antilles: Collision (ride de Beata, presqu'ile de Bahoruco): Subduction (fosse de Los Muertos), transtension (passage d'Anegada). PhD Thesis, University Pierre et Marie Curie, 300 p.

Jany I., Scanlon K. M. and Mauffret, A., 1990. Geological interpretation of combined Seabeam, Gloria and seismic data from Anegada Passage (Virgin Islands, north Caribbean). Mar. Geophys. Res. 12, 173-196. https://doi.org/10.1007/BF02266712 
Jolly W.T., Lidiak E.G., Schellekens J.H. and Santos, H., 1998. Volcanism, tectonics, and stratigraphic correlations in Puerto Rico. Geol. Soc. Am. Spec. Pap., 322, 1-34.

Land L.S., MacKenzi F.E. and Gould S.J., 1967. Pleistocene history of Bermuda. Geol. Soc. Amer. Bull., 78, 993-1106.

Larue D.K. and Warner AJ. 1991. Sedimentary basins of the NE Caribbean Plate boundary zone and their petroleum potential. J. Petr. Geol., 14. https://doi.org/10.1111/j.17475457.1991.tb00312.x

Laurencin M., Marcaillou B., Graindorge D., Klingelhoefer F., Lallemand S., Laigle M. and Lebrun J.-F., 2017. The polyphased tectonic evolution of the Anegada Passage in the northern Lesser Antilles subduction zone. Tectonics, 36, 945-961. https://doi.org/10.1002/2017TC004511

Laurencin M., Graindorge D., Klingelhoefer F., Marcaillou B. and Evain M., 2018. Influence of increasing convergence obliquity and shallow slab geometry onto tectonic deformation and seismogenic behavior along the Northern Lesser Antilles zone. Earth Planet. Sci. Lett., 492, 59-72

Lebrun J.F. and Lallemand S., 2017. Unpublished GARANTI cruise report. http://dx.doi.org/10.17600/17001200

Legendre L., 2018. Cinématique des déformations fragiles dans la partie Nord de l'arc des Petites Antilles. PhD Thesis, Université des Antilles.

Legendre L., Philippon M., Münch P., Leticée J. L., Noury M., Maincent, G., Cornée J.-J., 2018. Trench bending initiation: Upper plate strain pattern and volcanism. Insights from the Lesser Antilles arc, St Barthelemy Island, French West Indies. Tectonics, 37, 2777-2797. https://doi.org/10.1029/2017TC004921

Mac Donald R., Hawkesworth C. J. and Heath E., 2000. The Lesser Antilles volcanic chain: A study in arc magmatism. Earth Sci. Rev., 49, 1-76.

MacPhee R. D. E.,2005. 'First' appearances in the Cenozoic land-mammal record of the Greater Antilles: significance and comparison with South American and Antarctic records. $J$. Biogeogr., 32, 551-564.

MacPhee R.D.E. and Iturralde- Vinent M.A., 1995. Origin of the Greater Antillean land mammal fauna, 1: New Tertiary fossils from Cuba and Puerto Rico. Am. Mus. Novit. 3141, 130 .

Mann P., Taylor F.W., Lawrence Edwards R. and Ku T.,1995. Actively evolving microplate formation by oblique collision and sideways motion along strike-slip faults: An example from the northeastern Caribbean plate margin. Tectonophysics, 246,1-69.

Mann P., Hippolyte J.C., Grindlay N.R. and Abrams L.J., 2005. Neotectonics of southern Puerto Rico and its offshore margin, in: Mann, P. (Ed.), Active tectonics and seismic hazards of Puerto Rico, the Virgin Inslands and off-shore areas. Geol. Soc. Am. Spec. Paper, 385, 115138. 
Marcaillou B. and Klingelhoefer F., 2013. ANTITHESIS-1-Leg1 Cruise, RV L'Atalante, doi:10.17600/13010070.

Marcaillou, B., Klingelhoefer, F., 2016. ANTITHESIS-3 Cruise, RV Pourquoi Pas?, doi:10.17600/16001700

Marivaux L., Vélez-Juarbe J., Merzeraud G., Pujos F., Viñola López L. W., Boivin M., Santos-Mercado H., Cruz E. J., Grajales A., Padilla J., Vélez-Rosado K. I., Philippon M., Léticée J.-L., Münch P. and Antoine P.-O., 2020. Early Oligocene chinchilloid caviomorphs from Puerto Rico and the initial rodent colonization of the West Indies. Proc. Roy. Soc. B, 287, 20192806.

Martin-Kaye P.H.A., 1969. A summary of the geology of the Lesser Antilles. Overseas Geol. Miner. Resour., 10, 172-206.

Mascle A. and Westercamp D., 1983. Géologie d'Antigua, Petites Antilles. Bull. Soc. Géol. Fr., 7, 855-866.

Matchette-Downes C., 2007. Saba Bank, Dutch Antilles pestroleum potential.Saba Bank Petroleum Ressources, 19 pp. https://www.mdoil.co.uk/pdfs/Curacao.pdf

Mauffret A. and Jany I., 1990. Collision et tectonique d'expulsion le long de la frontière NordCaraïbe. Oceanologica Acta, spec. vol. 10, 97-116.

McCann W.R. and Sykes L.R., 1984. Subduction of aseismic ridges beneath the Caribbean Plate: Implications for the tectonics and seismic potential of the northeastern Caribbean. $J$. Geophys.Res. 89, 4493-4519, doi:10.1029/JB089iB06p04493.

Mittermeier R. A., Turner W. R., Larse, F. W., Brooks T. M. and Gascon, C., 2011.Global Biodiversity Conservation: The Critical Role of

Hotspots in Biodiversity Hotspots. Springer (eds Zachos F. E. and Habel J. C.), 3-22.

Montaggioni L. and Braithwaite C.J.R., 2009. Structure, zonation and dynamic patterns of coral reef communities. Developments in Marine Geology, 5, 67-122, Elsevier. doi: $\underline{10.1016 / \mathrm{S} 1572-5480(09) 05003-9}$

Multer H.G., Weiss M.P. and Nicholson D.V., 1986. Antigua; reefs, rocks and highroads of history. Leeward Island Science Associates, St John's, Antigua, Contrib. 1, 116 pp.

Münch P., Lebrun J.-F, Cornée J.-J., Thinon I., Guennoc P., Marcaillou B., Randrianasolo A. and the KASHALLOW TEAM, 2013. Pliocene to Pleistocene carbonate systems of the Guadeloupe archipelago, French Lesser Antilles: a land and sea study. Bulletin de la Société géologique de France, 184, 99-110.

Münch, P., Cornée, J.-J., Lebrun, J.F., Quillévéré, F., Vérati, C., Melinte-Dobrinescu, M., Demory, F.,Smith, M.J., Jourdan, X., Lardeaux, J.-M., De Min L., Léticée J.-L. and Randrianasolo A., 2014. Pliocene to Pleistocene vertical movements in the forearc of the Lesser Antilles subduction: insights from chronostratigraphy of shallow-water carbonate platforms (Guadeloupe archipelago). J.Geol.Soc. London, 171, 329-341. 
Myers N., Russell A., Mittermeier R.A., Mittermeier C.G., da Fonseca G.A.B. and Kent J., 2000. Biodiversity hotspots for conservation priorities. Nature, 403, 853-858.

Nagle F., Stipp J. J. and Fisher D. E., 1976. K-Ar geochronology of the limestone caribbees and Martinique, Lesser Antilles, West Indies. Earth Planet. Sci. Lett., 29, 401-412.

Nairn A. and Stehli F.G. eds.,1975. Geology of the Caribbean crust, Gulf of Mexico and the Caribbean. Plenum press, 1975.

Neill I., Kerr A. C., Hastie A. R., Stanek K. P. and Millar I. L.,2011. Origin of the Aves Ridge and Dutch-Venezuelan Antilles: Interaction of the Cretaceous 'Great Arc'and CaribbeanColombian Oceanic Plateau? J.Geol.Soc. London, 168, 333-348.

Padron C., Klingelhoefer F. Marcaillou B., Lebrun J.-F., Lallemand S., Garrocq C., Laigle M., Roest W. R., Schenini L., Beslier M.-O., Graindorge D., Gay A., Audemard F.,Münch Ph. and the GARANTI Cruise Team, 2020. Deep Structure of the Grenada Basin From Wide- Angle Seismic, Bathymetric and Gravity Data. J. Geoph. Res., 126, e2020JB020472. https://doi.org/10.1029/2020JB020466

Philippon M. and Corti G., 2016. Obliquity along plate boundaries. Tectonophysics, 693, 171182. https://doi.org/10.1016/i.tecto.2016.05.033

Philippon M., Cornée J.-J., Münch P., van Hinsbergen D.J.J., BouDagher-Fadel M., Gailler L., Quillévéré F., Boschman L., Montheil L., Gay A., Lebrun J.-F., Lallemand S., Marivaux L. and Antoine P.O., 2020a. Eocene intra-plate shortening responsible for the rise of a fauna pathway in the northeastern Caribbean realm. Plos-ONE, 15(10): e0241000.

https://doi.org/10.1371/journal.pone.0241000

Philippon M., Boschman L.M., Gossink L.A.W., Munch P., Cornée J.-J., Boudagher-Fadel M., Léticée J.L., Lebrun J.-F. and Van Hinsbergen D.J.J., 2020b. Paleomagnetic evidence from St. Barthélemy Island for post-Eocene rotation and deformation in the forearc of the curved Lesser Antilles subduction zone. Tectonophysics, 777, 228323. https://doi.org/10.1016/i.tecto.2020.228323

Pindell J. L. and Kennan L., 2009. Tectonic evolution of the Gulf of Mexico, Caribbean and northern South America in the mantle reference frame: an update. Geological Society, London, Special Publications 328, 1-55, doi:10.1144/SP328.1.

Presslee S., Slater, G. J., Pujos F., Forasiepi A. M., Fischer R., Molloy K., Mackie M., Olsen J. V., Kramarz A. G., Taglioretti M., Scaglia F., Lezcano M., Lanata J. L., Southon J., Feranec R., Bloch J. I., Hajduk A., Martin F. M., Salas-Gismondi R., Reguero M. A., de Muizon C., Greenwood A., Chait B. T., Penkman K., Collins M. and MacPhee R. D. E., 2019. Palaeoproteomics resolves sloth relationships. Nat. Ecol. Evol., 3, 1121-1130.

Railsback L.B., Gibbard P.L., Head M.J., Voarintsoa N.R.G. and Toucanne S., 2015. An optimized scheme of lettered marine isotope substages for the last 1.0 million years, and the climatostratigraphic nature of isotope stages and substages. Quat. Sci. Rev., 111, 94-106. Rankin D.W., 2002. Geology of St John, U.S. Virgin Islands. U.S. Geol. Surv. Prof. Paper $1631,36 \mathrm{pp}$.

Reed F.R.C., 1921. The Geology of the British Empire. Edward Arnold, London. 
Robinson E. D., Paytan A. D. and Chien C. T., 2017. Strontium isotope dates for the Oligocene Antigua Formation, Antigua, WI. Caribb. J. Earth Sci., 50, 11-18.

Roca A. L., Bar-Gal G., Eizirik E., Helgen K. M., Maria R., Springer M. S., O’Brien, S. J. and Murphy W. J., 2004. Mesozoic origin for West Indian insectivores. Nature, 429, 649-651.

Roksandic M.M., 1978. Seismic facies analysis concepts. Geophys. Prospect., 26, 383-398. Russell R. J. and McIntire W. J. 1966. Barbuda reconnaissance. Tech. Rep. coastal Stud. Inst La St Univ., 11 (J), 1-53.

Samper A, Quidelleur X, Lahitte P, Mollex D. 2007. Timing of effusive volcanism and collapse events within an oceanic arc island: Basse-Terre, Guadeloupe archipelago (Lesser Antilles Arc). Earth Planet. Sci. Letters 258, 175-191. DOI: 10.1016/j.epsl.2007.03.030.

Scotese, C.R., 2016. PALEOMAP PaleoAtlas for GPlates and the PaleoData Plotter Program, PALEOMAP Project, http://www.earthbyte.org/paleomap---paleoatlas---for---gplates

Speed R. C., Gerhard L. C. and McKee E. H., 1979. Ages of deposition, deformation, and intrusion of Cretaceous rocks, eastern St Croix, Virgin Islands. Geol. Soc. Amer. Bull., 90, 629-632.

Stéphan J.F., Mercier de Lépinay B., et al., 1990. Paleogeodynamics maps of the Caribbean14 steps from Lias to Present. Bull. Soc. géol. Fr. 6, 915-919.

Tucker M.E. and Wright, V.P., 1990. Diagenetic processes, products and environments. In: Carbonate Sedimentology. Blackwell Publishing Ltd, Oxford, U.K., 314-364.

Vail P. R., Mitchum R. M. and Thompson S., 1977, Seismic stratigraphy and global changes of sea level, Part 3: Relative changes of sea level from coastal onlap. In: Seismic Stratigraphy-Applications to Hydrocarbon Exploration (Ed. Payton, C. W.): American Association Geologists Memoir, 26, 83-97.

Van Duyle F.C. and Meesters E.H., 2018. Cruise report RV Pelagia 64PE433, Saba, St Eustatius and Saba Bank. 26 February-10 March 2018, St Maarten-St Maarten (NICO expedition leg 6). https://www.dcbd.nl/document/cruise-report-rv-pelagia-64pe433-saba-steustatius-and-saba-bank-benthic-habitat-mapping and https://www.saba-news.com/saba-bank-hasthe-deepest-and-largest-marine-sinkholes-in-the-world/

Van Wagoner C., Posamentier H. W., M. Mitchum R., Vail P. R., Sarg J. F., Loutit T. S. and J. Hardenbol J., 1988. An overview of the fundamentals of sequence stratigraphy and key definitions. In: Sea-Level Changes-An Integrated Approach, SEPM Special Publication, 42, $39-45$

Wade B.S., Pearson P.N., Berggren W.A. and Paëlike H., 2011. Review and revision of Cenozoic tropical planktonic foraminiferal biostratigraphy and calibration to the geomagnetic polarity and astronomical time scale. Earth Sci. Rev., 104, 111-142.

Warner A.J., 1990. The Cretaceous age sediments of the Saba Bank and their petroleum potential. In: Larue DK, Draper G (eds), Trans. 12 th Caribbean Conference, St Croix. Miami Geol. Soc., South Miami, 341-354 
Watters D., Donahue J. and Stuckenrath R., 1991. Paleoshorelines and the prehistory of Barbuda, West Indies. In: Paleoshorelines and Prehistory: an investigation method (Jonhson

Weiss M.P., 1994. Oligocene limestones of Antigua, West Indies: Neptune succeeds Vulcan. Caribb. J. Earth Sci., 30, 1-29.

Westercamp D., 1988. Magma generation in the Lesser Antilles: geological constraints.

Westercamp D., Andréïeff P., Bouysse P. and Mascle A.,1985. The Grenadines, southern

Woods C. A., Borroto Paéz R. and Kilpatrick C. W. 2001. Insular patterns and radiations of West Indian rodents. In: Biogeography of the West Indies: Patterns and Perspectives (Woods C. A. and Sergile F. E. Eds), 335-353. Boca Raton: CRC Press.

Wright V. P. and Burchette T. P., 1996. Shallow-water carbonate environments. In:

Sedimentary Environments: Processes, Facies, and Stratigraphy (ed. H. G. Reading), 325-94. Oxford, Blackwell Science.

Zachariasse W.J., van Hinsbergen D.J.J. and Fortuin A.R., 1988. Mass wasting and uplift on Crete and Karpathos during the early Pliocene related to initiation of south Aegean left- 